\title{
As eleições para prefeito no Rio de Janeiro: uma análise sobre partidos, coligações e a política subnacional
}

\author{
Mayoral elections in Rio de Janeiro: an analysis of parties, coalitions and \\ subnational politic
}

\author{
Rodrigo Dolandeli dos Santos \\ Doutorando do Programa de Pós-graduação em \\ Ciência Política, Universidade Estadual de Campinas \\ (UNICAMP), Campinas, SP, Brasil \\ dolandeli@gmail.com
}

\section{Letícia Bona Travagin}

Mestranda do programa de Pós-graduação em Desenvolvimento Econômico, Universidade Estadual de Campinas (UNICAMP), Campinas, SP, Brasil leticiatravagin@gmail.com
Resumo: O objetivo deste artigo é analisar o desempenho dos partidos nas campanhas para prefeito entre 1996 a 2012 no estado do Rio de Janeiro. O trabalho estrutura-se da seguinte forma: a) uma breve análise histórica das disputas eleitorais na capital carioca; b) uma descrição da força eleitoral do partido do governador nos pleitos locais, compreendendo a eleição de prefeitos e coligações; c) uma análise descritiva dos testes estatísticos de associação entre variáveis categóricas políticas e socioeconômicas, tais como a nacionalização e consistência das coligações partidárias, a trajetória eleitoral dos competidores, a magnitude do distrito eleitoral; por último, d) um exame detalhado sobre a migração partidária dos candidatos a prefeito. Os resultados confirmam que o partido do governador altera sua estratégia à medida que a magnitude do distrito eleitoral varia. A pesquisa sugere ainda que restrições institucionais, tais como a decisão do judiciário sobre a infidelidade partidária, impactaram diretamente nas estratégias coligacionistas do executivo estadual nas eleições municipais.

Palavras-chave: Eleições municipais; Partidos políticos; Coligações eleitorais; Esfera subnacional; Migração partidária.

Abstract: The objective of this paper is to analyze the performance of parties in campaigns for mayor between from 1996 to 2012 in the state of Rio de Janeiro. The study is structured as follows: a) a brief historical analysis of electoral disputes in the capital of Rio de Janeiro; b) a description of the governor's electoral strength on local elections, comprising the election of the mayors and his coalitions; c) a descriptive analysis of the statistical association tests between political and socio-economic categorical variables, such as the nationalization and consistency of party coalitions, the electoral trajectory of competitors and the magnitude of the electoral district; and finally, d) a detailed examination about the party migration of the mayors candidates. The results confirm that the governor's party changes its strategy as the magnitude of the electoral district varies. The research also suggest that institutional constraints, as the court's decision on the partidary migration, have impacted directly on the strategies executive's state coalitions in municipal elections.

Keywords: Municipal elections; Political parties; Electoral coalitions; Subnational sphere; Partidary migration. 


\section{Introdução}

A dinâmica das eleições municipais tem atraído a atenção de muitos pesquisadores preocupados em explicar não apenas a política local, mas sobretudo os impactos destes pleitos em nível nacional. Podemos notar esta abordagem em diversos trabalhos, tais como, Ames (1994), Fleischer (2002) e Samuels (2000). Barry Ames (1994), por exemplo, assinalou que o apoio de prefeitos é fundamental para as campanhas presidenciais. Por sua vez, David Samuels (2000) reservou aos governadores o papel de aliados imprescindíveis. O caminho inverso igualmente é observado em estudos que destacam a influência da política nacional sobre as eleições locais (ALVES, 2007; BORGES 2007; PEIXOTO, 2008).

AConstituição de 1988 proporcionou aos municípios maior peso político. Tornaram-se um ente da federação, tal como os estados e a União, adquirindo maior autonomia administrativa. Da mesma forma, elevaram seus níveis de captação de repasses financeiros institucionais. No entanto, dos mais de cinco mil municípios brasileiros, uma parte considerável depende demasiadamente de verbas federais. Desde a promulgação da nova constituição, mais de 1.300 municípios foram criados. Destes, aproximadamente $90 \%$ possuem menos de 50 mil habitantes, tendo $80 \%$ de suas despesas cobertas por transferências institucionais (KERBAUY, 2008). Este quadro reforçaria o suposto de que relações políticas personalistas e clientelistas se disseminariam no poder local, um dos pontos mais observados pela literatura especializada. Victor Nunes Leal (1997), em seu clássico "Coronelismo, enxada e voto", retratou as formas de dominação política que se desenvolviam nesta esfera. Assim como José Murilo de Carvalho (1997) que, ao discorrer sobre as transformações históricas do fenômeno, examinou a concentração do poder das oligarquias, potencializada por um novo ator político em ascensão: o governador de estado. Neste sentido, a dependência da política partidária local por redes clientelistas, lideradas por elites regionais, seria, por vezes, na política contemporânea municipal, coordenada pela figura do governador.

Contudo, outros elementos são igualmente importantes para compreender as eleições municipais. Algumas análises procuram desvendar os incentivos proporcionados pelas instituições políticas. Pereira e Rennó (2007), por exemplo, demonstraram como o eleitorado preocupa-se mais com os benefícios locais do que com a performance do parlamentar na Câmara dos Deputados. O executivo federal, dessa forma, seria incentivado a se utilizar da aplicação das emendas orçamentárias coletivas e individuais dos parlamentares para influenciar a correlação de forças da política nos municípios, constituindo bases de apoio fundamentais nas eleições.

Em geral, as clivagens locais, dada a sua pluralidade de elementos, não somente política, mas sobretudo social e cultural, acabam se sobrepondo aos interesses partidários de instâncias estaduais ou mesmo nacionais. Assim, a tarefa de mensurar estas particularidades no país tem sido um grande desafio para os cientistas políticos.

Procuramos analisar neste artigo a competição política no estado do Rio de Janeiro, terceiro maior colégio eleitoral do país, visando contribuir com os estudos acerca das coligações, bem como, da "nacionalização" e "presidencialização" das campanhas (CORTEZ, 2009). Não deixando de considerar também que as eleições fluminenses têm se configurado em uma dinâmica própria na qual as agremiações que polarizam o sistema político brasileiro (PT e PSDB) poucas vezes foram protagonistas.

Propomo-nos a examinar se a estrutura política municipal reflete em maior proporção ou não os arranjos nacionais (DANTAS, 2007; 2009; PEIXOTO, 2008). Para este fim, pesquisamos as campanhas para prefeito e a "força" política do governador entre as eleições de 1996 e 2012. O objetivo deste estudo é debater o desempenho das legendas e propor hipóteses, considerando os incentivos do presidencialismo de coalizão reproduzidos nos estados, assunto que enquadra boa parte da produção acadêmica (ABRÚCIO, 1998; BORGES, 2010; LIMA JUNIOR, 1983; MAINWARING, 2001). Igualmente, analisamos outros aspectos institucionais explicativos, como o advento da reeleição para os cargos executivos (SAMUELS, 2001; PEREIRA; RENNÓ, 2007; BARRETO, 2009).

A estrutura do texto tem a seguinte ordem: a) uma breve análise histórica das disputas eleitorais na capital do Rio de Janeiro de 1992 a 2012; b) uma descrição da força eleitoral do partido do governador nos pleitos locais, compreendendo a eleição de prefeitos e coligações; c) uma análise descritiva dos testes estatísticos de associação entre variáveis categóricas políticas e socioeconômicas, tais como a nacionalização e consistência das coligações partidárias, a trajetória eleitoral dos competidores e a magnitude do distrito eleitoral; e por último, d) um exame detalhado sobre a migração partidária dos candidatos a prefeito.

\section{As campanhas eleitorais na Capital do Rio de Janeiro}

Nas pesquisas sobre o federalismo, há uma interpretação de que as estratégias partidárias podem ser mais inteligíveis, quando observadas sob a ótica estadual (LIMA JUNIOR, 1983). Uma das razões seria 
a natureza descentralizada das organizações, incentivada pela estrutura federativa do país (PANEBIANCO, 2005). Neste sentido, observar o desenvolvimento das alianças eleitorais das capitais, cidades estratégicas dos estados brasileiros, pode nos dizer muito sobre a maneira como os partidos coordenam seus recursos. Visto que, a competição entre as principais lideranças no estado, cristalizam-se nas disputas pela prefeitura do Rio de Janeiro. Este suposto foi tratado por Dantas (2009), cuja pesquisa demonstrou como mais de $70 \%$ dos governadores elegeram prefeitos de capitais aliados nas eleições municipais de 2000.

As clivagens partidárias recentes no estado ainda trazem consigo muitos aspectos do rearranjo das forças políticas construído durante a transição democrática. Nas palavras de Montero (2001, p. 61-62), uma boa reconstituição do período no Rio de Janeiro:

These bosses [chefes políticos] expanded Rio's politics beyond the narrow clientelism of the Old Republic by constructing a mass base of patrimonial support [...] Factions linked to the urban political machine of Antonio de Padua Chagas Freitas (the chaguistas), leftists known as autenticos (authentics), who challenged military rule and opposed Chagas Freitas's own close ties to the generals, and independents or members of the political machine of ex-governor Ernani do Amaral Peixoto (the so-called amaralistas) battled for control of state politics [...] During and after the transition to democracy, this legacy of populist government continued. With his political rights restored in 1979, Leonel Brizola, a former governor of Rio Grande do Sul and federal deputy from Guanabara, returned from exile to Rio de Janeiro. [...] Brizolismo added yet another current to the widest array of competing political interests in any state of Brazil.

Da eleição para governador em 1982, vencida por Leonel Brizola, histórica liderança nacional, até o início da década de 2000, o PDT polarizou a política fluminense. Inicialmente, contra o PMDB na década de 1980 e em seguida, a partir dos anos 1990, enfrentando quadros egressos do próprio partido ${ }^{1}$. O PMDB, por sua vez, consolidou-se politicamente no estado desde a ditadura militar, ainda como MDB, quando governou o estado da Guanabara e também o do Rio de Janeiro².

\footnotetext{
${ }^{1}$ César Maia (PMDB, PTB e PFL/DEM), deputado federal, prefeito e vereador da capital; Marcello Alencar (PSDB), senador, prefeito da capital e governador; e Anthony Garotinho (PSB, PMDB e PR), prefeito de Campos dos Goytacazes, governador e deputado federal, foram quadros importantes da política fluminense que saíram do PDT.

2 Em 1960 foi criado o estado da Guanabara quando a capital federal migrou da cidade do Rio de Janeiro para Brasília. Em seguida, ocorreu a fusão entre o estado da Guanabara e o do Rio de Janeiro no ano de 1975, passando a antiga capital federal a ser a nova capital do estado. O PMDB neste período governou os dois estados com Chagas Freitas.
}

Em seguida, como mencionado acima, alternou com o brizolismo, elegendo o então prefeito de Niterói, Moreira Franco, em 1986. Contudo, os peemedebistas somente foram recuperar este protagonismo político estadual no início dos anos $2000^{3}$.

Neste período cabe notar que, tanto PT, quanto PSDB, partidos que polarizam o sistema partidário nacional desde meados da década de 1990, poucas vezes destacaram-se na política fluminense. Os tucanos elegeram Marcello Alencar para o governo em 1994, mas o mesmo não tentou a reeleição por conta de baixos índices de popularidade. O PSDB ainda ocupou a vice-prefeitura do Rio de Janeiro com Otávio Leite na reeleição de Cesar Maia em 2004. Por sua vez, o PT elegeu a vice-governadora, Benedita da Silva, aliado a Anthony Garotinho (PDT) em 1998. Ela chegou a governar o estado por um breve período em 2002, em virtude de Garotinho ter renunciado ao cargo para disputar a corrida presidencial. Além disso, os petistas elegeram o vice-prefeito da capital, Adilson Pires, na chapa vitoriosa da reeleição de Eduardo Paes (PMDB) em 2012. Ou seja, em poucos momentos da política estadual houve protagonismo destas duas legendas nacionais ${ }^{4}$.

De uma forma geral, as eleições nas capitais deram o tom do mercado eleitoral estadual, cujos contextos das disputas mais recentes descreveremos a seguir.

\section{2}

A eleição de 1992 evidenciou uma das primeiras deserções importantes no seio do brizolismo. César Maia filiou-se ao PMDB por ter sido preterido no PDT, que decidiu lançar a então deputada federal Cidinha Campos. No entanto, mesmo favorita nas pesquisas de intenção de voto e apoiada pelo governador Brizola ela não chegou ao segundo turno, disputado entre a

\footnotetext{
Embora o PMDB já tenha governado o estado durante a ditadura militar e também em 1986, apenas quando o ex-governador Anthony Garotinho e sua esposa, a então governadora Rosinha Garotinho, filiaram-se ao partido em 2003, a legenda retoma um processo de hegemonia política. A partir desse regresso à máquina estadual, o partido venceu três eleições estaduais consecutivas: Sérgio Cabral (2006 e 2010) e Luiz Fernando Pezão em 2014. Da mesma forma, desde 2008 o PMDB governa conjuntamente o estado e a capital Rio de Janeiro, quanto Eduardo Paes foi eleito em 2008 e reeleito em 2012. Desde a redemocratização, somente o PDT em 1985, quando Leonel Brizola era governador e elegeu Saturnino Braga prefeito da capital, conseguiu ter ao mesmo tempo o governo estadual e a prefeitura da cidade do Rio de Janeiro.

${ }^{4}$ Quanto ao restante das cidades acima de 200 mil eleitores do estado, o PSDB teve seu auge na eleição municipal de 1996 quando governava o estado. No período observado os tucanos já venceram em Duque de Caxias (1996, 2000 e 2008), Nova Iguaçu (1996 e 2000) e Petrópolis (1996), além de Niterói em 2004. No entanto, não elege um prefeito nestas cidades desde 2008. Já o PT somente veio a governar grandes cidades no estado em 2004. Os petistas já venceram em Nova Iguaçu (2004 e 2008) e Niterói (2004 e 2012). Em 2008 também conquistaram as prefeituras de Belford Roxo e Petrópolis.
} 
deputada federal Benedita da Silva (PT) e Cesar Maia (PMDB). Este último venceu o pleito, fato que se repetiria em 2000 e 2004. O PSDB também lançou candidato, o deputado estadual Sérgio Cabral, que obteve apenas $2 \%$ dos votos.

\section{6}

Os candidatos Miro Teixeira, deputado federal pelo PDT, e Sérgio Cabral (PSDB), então presidente da Assembleia Legislativa (ALERJ), polarizaram o início da campanha. O primeiro, indicado por Brizola ${ }^{5}$. O segundo, apoiado pelo governador Marcello Alencar. Apesar do contorno nacional da disputa, dada a forte oposição de Leonel Brizola ao governo do presidente Fernando Henrique Cardoso (PSDB), PFL e PSDB não caminharam juntos. Os dois principais partidos da coalizão federal romperam às vésperas devido a desavenças entre o governador tucano e o prefeito César Maia, recém-filiado ao PFL, uma rivalidade antiga desde os tempos que militavam no PDT. Os pefelistas acabaram lançando o desconhecido secretário municipal de urbanismo do prefeito, Luiz Paulo Conde, que venceu as eleições contra Sérgio Cabral. O PT, com o vereador Chico Alencar, teve uma boa votação, 21,7\%, mas não o suficiente para mais uma vez ir ao segundo turno da capital carioca.

\section{0}

O cenário eleitoral de 2000 repetiu o de 1996 em alguns aspectos. O prefeito Luiz Paulo Conde (PFL), tentou a reeleição, mas não obteve sucesso. Ele conseguiu o apoio tanto do PMDB, que declinou da candidatura de Sérgio Cabral, ex-PSDB, quanto do governador da época, Anthony Garotinho (PDT), que não aderiu à candidatura da liderança maior de sua própria agremiação, o ex-governador Leonel Brizola. Por sua vez, a reeleição de Conde não teve o suporte dos tucanos que lançaram o deputado federal Ronaldo Cezar Coelho, "retribuindo" a falta de apoio dos pefelistas na eleição passada. A vice-governadora Benedita da Silva (PT) disputou a eleição novamente, mas ficou em terceiro lugar, atrás do ex-prefeito Cesar Maia. Este último, concorrendo por outro partido (PTB), pois fora preterido pelo PFL, ganhou folego na reta final e venceu o segundo turno contra seu "afilhado" político Conde.

\section{4}

O prefeito Cesar Maia, de volta ao PFL, não encontrou resistências para se reeleger já no primeiro turno. Curiosamente, a aliança PSDB-PFL desta vez

\footnotetext{
${ }^{5}$ Ironicamente, Miro Teixeira havia sido o candidato do PMDB para o governo do estado em 1982, a primeira vencida por Leonel Brizola.
}

ocorreu, porém em um contexto nacional diferente. Agora as duas agremiações não pertenciam mais a uma coalizão federal governista, mas sim oposicionista. Tratava-se, portanto, das primeiras eleições municipais sob o governo do presidente Lula (PT). Os petistas lançaram o deputado federal Jorge Bittar, que já havia disputado uma eleição para prefeito em $1988^{6}$, mas somou apenas $6,3 \%$ dos votos, ficando abaixo inclusive da votação obtida pela deputada federal Jandira Feghali (PC do B), integrante da base aliada federal. Igualmente sem sucesso, o PDT teve candidatura própria lançando o ex-governador Nilo Batista, eleito como vice de Brizola em 1990. Nestas eleições, o ex-governador Anthony Garotinho, assim como, a então governadora Rosinha Garotinho, já integravam os quadros do PMDB fluminense. Em virtude desta articulação, Luiz Paulo Conde, ex-prefeito e vice-governador de Rosinha, disputou as eleições pelo PMDB, embora tenha alcançado apenas a terceira colocação, ficando atrás do senador Marcelo Crivella, candidato pelo PL.

\section{8}

Em 2008 tivemos na capital carioca a primeira eleição open seat após a regra da reeleição. O prefeito Cesar Maia (DEM), impossibilitado pela legislação de concorrer novamente, não conseguiu fazer a sua sucessora, a deputada federal Solange Amaral (DEM). A exemplo das eleições anteriores, partidos da mesma base governista federal não fecharam acordo em torno de uma candidatura unificada. O PT esperava o apoio dos peemedebistas para seu candidato, o deputado estadual Alessandro Molon, que acabou obtendo apenas 5\% dos votos, metade da votação alcançada por Jandira Feghali (PC do B). No entanto, o governador, Sérgio Cabral, apoiou seu secretário estadual de esportes e turismo, ex-deputado federal Eduardo Paes (PMDB). $\mathrm{O}$ candidato peemedebista venceu as apertadas eleições no segundo turno contra o deputado federal Fernando Gabeira (PV), apoiado também pelo PSDB. Dentre outros aliados em nível nacional, o deputado estadual Paulo Ramos (PDT) teve um fraco desempenho. Mas o senador Marcelo Crivella, agora candidato pelo PRB, legenda criada pelo então vice-presidente da República José Alencar, ficou em terceiro lugar.

\section{2}

A reeleição do prefeito Eduardo Paes (PMDB) ocorreu no primeiro turno. Esta foi a campanha com maior alinhamento nacional da séria histórica observada, a julgar pelo fato de todas as principais forças aliadas no plano federal (PMDB, PT, PC do B,

\footnotetext{
${ }^{6}$ Na ocasião o petista ficou em $2^{\circ}$ lugar perdendo para Marcello Alencar do PDT
} 
PSB, PDT, PP) estarem coligadas à chapa eleitoral do prefeito. No entanto, o mesmo não aconteceu no campo oposicionista. O PSDB lançou o deputado federal Otávio Leite, ex-vice-prefeito da gestão Cesar Maia, alcançando uma votação de apenas $2,5 \%$ dos votos. Resultado semelhante ao obtido pela aliança entre o deputado federal Rodrigo Maia (DEM), candidato a prefeito, e a deputada estadual Clarissa Garotinho (PR), candidata à vice. Esta coligação marcou o encontro de antigos rivais surgidos no seio do brizolismo, que inclusive já protagonizaram o segundo turno da eleição para governador de 1998, César Maia e Anthony Garotinho, este último rompido com o PMDB. Contudo, muito em função da fraca performance desta aliança, não houve segundo turno, mesmo a despeito do deputado estadual Marcelo Freixo (PSOL), segundo colocado na campanha, ter alcançado quase 1 milhão de votos $(28,2 \%)$.

Descrever o contexto eleitoral da capital nos serve para ilustrar como em certas ocasiões os partidos ficaram a reboque dos interesses específicos de determinadas lideranças partidárias. As eleições de 1996 e 2000, quando PFL e PSDB lançaram candidatos próprios, ou mesmo a campanha de 2008, com o PMDB decidindo de última hora não se aliar ao PT, demonstram que os arranjos partidários nacionais, por si só, podem ser insuficientes para a construção de alianças mais amplas. Mas por outro lado, a consistência das coligações ficou evidente, uma vez que não identificamos qualquer composição de chapas entre legendas que se opõem em nível federal.

\section{Desempenho eleitoral partidário nos municípios}

Nesta parte do artigo passamos a observar detalhadamente os dados pesquisados sobre as campanhas para prefeito no estado do Rio de Janeiro de 1996 a 2012. O estudo tem como fonte os arquivos disponibilizados eletronicamente pelo Tribunal Superior Eleitoral - TSE.

Contabilizamos nesta série histórica 458 prefeitos eleitos, dos quais, apenas nove partidos (PMDB, PDT, PSDB, PP/PPB, PT, PFL/DEM, PSB, PL/PR e PSC) elegeram juntos cerca de $90 \%$ dos mandatos, conforme podemos observar no Quadro 1. Vimos também que estas mesmas legendas foram as responsáveis por $70,8 \%$ do total de candidatos.

O PMDB figurou como a organização que mais elegeu prefeitos $(27,9 \%)$, muito acima do segundo colocado, PDT, que somou $12,2 \%$. O PSDB ficou na terceira posição e o PT em quinto, logo atrás do PP.

Embora os peemedebistas tenham se destacado pelo enraizamento partidário nos municípios, dois aspectos não podem deixar de serem detalhados sobre este ponto: o tamanho dos municípios e as coligações.

A produção acadêmica já observou como as estruturas de oportunidade, definidas pelas regras eleitorais, alteram-se dado o nível de magnitude do distrito (NICOLAU, 1996). Mainwaring, Meneguello e Power (2000), por sua vez, ressaltaram que, especialmente nos municípios menores e menos desenvolvidos, verificou-se maior apoio do eleitorado a partidos de direita e de centro. Embora, os autores também tenham alertado que, a partir das eleições de $1994 \mathrm{e}$ 1998, ampliou-se relativamente o sucesso eleitoral da esquerda nestas cidades.

Sobre as coligações, este fenômeno vem sendo retratado pela maior parte dos pesquisadores, desde o regime democrático do período 1946-1964, como um dos maiores problemas do sistema eleitoral, especialmente em se tratando das eleições proporcionais (LIMA JUNIOR, 1983; KRAUSE, 2010). Por não haver qualquer regra que ordene a distribuição das cadeiras entre os partidos (NICOLAU, 2002), com base na votação alcançada por eles, as coligações acabam por distorcer a representação política. Esta interpretação nos leva a perceber que agremiações nacionalmente pouco representativas garantem assento no Congresso Nacional, resultando em maior fragmentação partidária, que, por sua vez, eleva o custo político para a formação de coalizões. Segundo Dantas (2007), as legendas chegam a maximizar cerca de $50 \%$ suas chances de vitória, tornando-se as alianças um recurso valioso para partidos elegerem seus candidatos.

Quadro 1. Partidos e candidatos. Eleições de 1996 a 2012.

\begin{tabular}{|l|cccc|}
\hline \multicolumn{1}{|c|}{ Partidos } & N & $\mathbf{\%}$ & Eleitos & $\mathbf{\%}$ \\
\hline PMDB & 264 & 15,5 & 128 & 27,9 \\
PDT & 201 & 11,8 & 56 & 12,2 \\
PSDB & 145 & 8,53 & 51 & 11,1 \\
PP / PPB & 120 & 7,06 & 50 & 10,9 \\
PT & 155 & 9,12 & 33 & 7,21 \\
DEM / PFL & 90 & 5,29 & 30 & 6,55 \\
PSB & 74 & 4,35 & 26 & 5,68 \\
PR / PL / PRONA & 98 & 5,76 & 18 & 3,93 \\
PSC & 56 & 3,29 & 17 & 3,71 \\
Subtotal (n=9) & 1203 & 70,8 & 409 & 89,3 \\
Outros (n=33) & 497 & 29,2 & 49 & 10,7 \\
Total & $\mathbf{1 7 0 0}$ & $\mathbf{1 0 0}$ & $\mathbf{4 5 8}$ & $\mathbf{1 0 0}$ \\
\hline
\end{tabular}

Fonte: Quadro elaborado pelos autores com base em dados do TSE e TRE-RJ (BRASIL, 2014). 
Quadro 2. Partido do Governador e sucesso eleitoral com partidos coligados. Eleições 1996-2012.

\begin{tabular}{|c|c|c|c|c|c|c|c|c|c|c|c|c|}
\hline \multirow[b]{2}{*}{$\begin{array}{c}\text { Eleições } \\
\text { (Partidos/ } \\
\text { Gov) }\end{array}$} & \multicolumn{4}{|c|}{ Acima 200 mil ele. $(N=10)$} & \multicolumn{4}{|c|}{ Abaixo 200 mil ele. $(N=82)$} & \multicolumn{4}{|c|}{ Todos Municípios ( $\mathbf{N}=92$ ) } \\
\hline & $\begin{array}{c}\text { Cabeça } \\
\text { de } \\
\text { Chapa }\end{array}$ & Coligado & Total & $\%$ & $\begin{array}{c}\text { Cabeça } \\
\text { de } \\
\text { Chapa }\end{array}$ & Coligado & Total & $\%$ & $\begin{array}{c}\text { Cabeça } \\
\text { de } \\
\text { Chapa }\end{array}$ & Coligado & Total & $\%$ \\
\hline $\begin{array}{l}1996 \text { - PSDB } \\
\text { Marcello } \\
\text { Alencar }\end{array}$ & 3 & 0 & 3 & $30 \%$ & 24 & 6 & 30 & $36,6 \%$ & 27 & 6 & 33 & $35,9 \%$ \\
\hline $\begin{array}{l}2000-\text { PDT } \\
\text { Anthony } \\
\text { Garotinho }\end{array}$ & 3 & 1 & 4 & $40 \%$ & 31 & 11 & 42 & $51,2 \%$ & 34 & 12 & 46 & $50,0 \%$ \\
\hline $\begin{array}{l}2004 \text { - PMDB } \\
\text { Rosinha } \\
\text { Garotinho }\end{array}$ & 3 & 1 & 4 & $40 \%$ & 38 & 6 & 44 & $53,7 \%$ & 41 & 7 & 48 & $52,2 \%$ \\
\hline $\begin{array}{l}2008 \text { - PMDB } \\
\text { Sérgio Cabral }\end{array}$ & 3 & 0 & 3 & $30 \%$ & 32 & 12 & 44 & $53,7 \%$ & 35 & 12 & 47 & $51,1 \%$ \\
\hline $\begin{array}{l}2012 \text { - PMDB } \\
\text { Sérgio Cabral }\end{array}$ & 3 & 2 & 5 & $50 \%$ & 22 & 19 & 41 & $50 \%$ & 25 & 21 & 46 & $50,0 \%$ \\
\hline
\end{tabular}

Fonte: Quadro elaborado pelos autores com base em dados do TSE e TRE-RJ (BRASIL, 2014).

Outros exemplos da literatura serão observados ao longo do texto. No entanto, em meio a estas ressalvas, passamos a analisar mais detalhadamente os dados eleitorais.

Primeiramente, classificamos as cidades por faixas populacionais: abaixo e acima de 200 mil eleitores. Justamente a divisão posta pela legislação para que haja possibilidade de segundo turno nas campanhas de cargos executivos. Em segundo lugar, a fim de evidenciar a força do governo estadual nas eleições observamos também as coligações por ele realizadas.

Assim, vimos no Quadro 2, à exceção do pleito de 1996, que aproximadamente metade dos eleitos em algum grau esteve conectado ao governador, caso consideremos as coligações. Os tucanos elegeram 27 prefeitos e se coligaram em mais 6 chapas vitoriosas, ficando presente em $35,9 \%$ das 92 prefeituras do estado. Nas eleições seguintes, tanto o PDT, quanto o PMDB, tiveram um desempenho superior.

Especificamente sobre o PMDB observamos uma certa mudança de estratégia. O partido pulou de 7 eleições coligadas sem cabeça de chapa em 2004 para $21 \mathrm{em} 2012^{7}$. Em outras palavras, os peemedebistas continuaram fortes eleitoralmente, mantendo-se em metade das chapas vitoriosas do estado, mesmo com a perda de muitas prefeituras neste período: de $41 \mathrm{em}$ 2004 baixaram para $25 \mathrm{em} 2012$.

\footnotetext{
${ }^{7}$ Cabe ressaltar que nas cidades acima de 500 mil habitantes (Rio de Janeiro, Duque de Caxias, Nova Iguaçu e São Gonçalo), o partido do governador não se coligou nenhuma vez entre 1996 a 2012. PSDB, PDT, e PMDB lançaram candidatos próprios nestes municípios em todas as cinco eleições observadas quando governavam o estado.
}

Muito desse sucesso eleitoral do partido do governador ocorreu nas cidades com menos de 200 mil eleitores. No Rio de Janeiro elas representam $90 \%$ do total. Por sua vez, nas 10 maiores cidades os governadores tiveram rigorosamente 3 prefeitos aliados eleitos em cada campanha observada. Assim, em 2012, além do PMDB ter conquistado 3 prefeituras, ele esteve coligado a mais duas chapas vitoriosas, integrando grupos políticos que governam metade das principais cidades do estado, algo não alcançado por nenhum partido da série observada ${ }^{8}$.

É importante frisar que o governador a cada eleição enfrenta grandes dificuldades para montar chapas competitivas nestes pleitos, basicamente por duas razões. Uma, de natureza socioeconômica, seria a maior dispersão das legendas em virtude do interesse delas administrarem cidades dotadas de recursos mais fartos, elevando sua projeção política. Outra, teria a ver com os incentivos institucionais da legislação, uma vez que a possibilidade de segundo turno permite aos partidos um realinhamento na fase seguinte do processo eleitoral, caso não tenham obtido êxito no primeiro turno (DUVERGER, 1970).

Por outro lado, nas cidades abaixo de $200 \mathrm{mil}$ eleitores, onde as agremiações lançam menos candidatos a prefeito, há uma dinâmica diferente, caracterizada pela

\footnotetext{
${ }^{8}$ Em 1992, o PDT do governador Leonel Brizola elegeu 5 prefeitos entre as 10 maiores cidades: Petrópolis, Campos dos Goytacazes, Niterói, Nova Iguaçu e São Gonçalo. No entanto, não utilizamos esta eleição, bem como as anteriores, na série histórica observada.
} 
forte tendência à polarização política e ao personalismo (DANTAS, 2007, 2009; NICOLAU, 1996) ${ }^{9}$.

Para detalharmos a descrição destes dados eleitorais, analisaremos, a seguir, as categorias: a) PartGov, trata-se do partido do governador nas diferentes eleições; b) Maiores Partidos, agrega o resultado eleitoral dos principais partidos da política estadual e nacional (PMDB, PDT, PSDB, PT e PFL/DEM), excluindo a legenda quando a mesma equivaler a do governante na respectiva eleição observada; c) Outros Partidos, soma o restante das legendas não incluídas na variável "Maiores Partidos"; e d) GOV/Coligado, trata-se do desempenho do partido governante, seja como "cabeça de chapa", seja como coligado na chapa eleitoral majoritária, conforme já observado no Quadro 2.

Nos Gráficos 1a, b, constatamos uma ascensão de partidos considerados menores ("Outros Partidos") no último pleito, ultrapassando, inclusive, a porcentagem do partido governante quando coligado ("GOV/Coligado") nas cidades abaixo de 200 de mil eleitores. Além disso, apesar de nos maiores municípios a distribuição oscilar, os partidos de menor expressão já somavam cerca de $30 \%$ das prefeituras no restante das cidades entre 1996 e 2008. Para consultar os valores completos das porcentagens, bem como a descrição das variáveis dos Gráficos 1a, b, verificar as Tabelas A1 e A2 do Anexo A ao final do artigo.

Estes dados, além de mostrarem o declínio dos maiores partidos nas campanhas municipais, anunciavam ao mesmo tempo um avanço da fragmentação partidária, como acabou por ocorrer nas eleições gerais de 2014.

No Gráfico 2 confirmamos o salto dado entre 2008 e 2012 de partidos efetivos (NEP) no Rio de Janeiro ${ }^{10}$. O cálculo mostra oito partidos relevantes em quantidade de prefeituras, valor elevado sem precedente na série observada.

\section{Eleções open seat e coligações}

Até o momento descrevemos a distribuição do sucesso eleitoral dos partidos, observando particularmente o desempenho da legenda do governador, como cabeça de chapa ou coligado. Nesta seção apresentaremos duas variáveis que julgamos serem fundamentais para influenciar a intensidade da associação entre o apoio do governador e o êxito eleitoral: a) as eleições open seat; e b) a consistência das coligações partidárias.

\footnotetext{
${ }_{9}^{9}$ Para Dantas (2007) em 2000, os municípios tiveram $84 \%$ de suas campanhas com os dois primeiros colocados acumulando $80 \%$ dos votos. Em 2004 este índice ficou próximo, caindo para $82 \%$.

10 Para calcular a efetividade dos candidatos utilizamos a fórmula de fragmentação partidária de Laakso e Taagepera (1979). Este índice é utilizado para identificar o número de partidos efetivos em uma eleição.
}

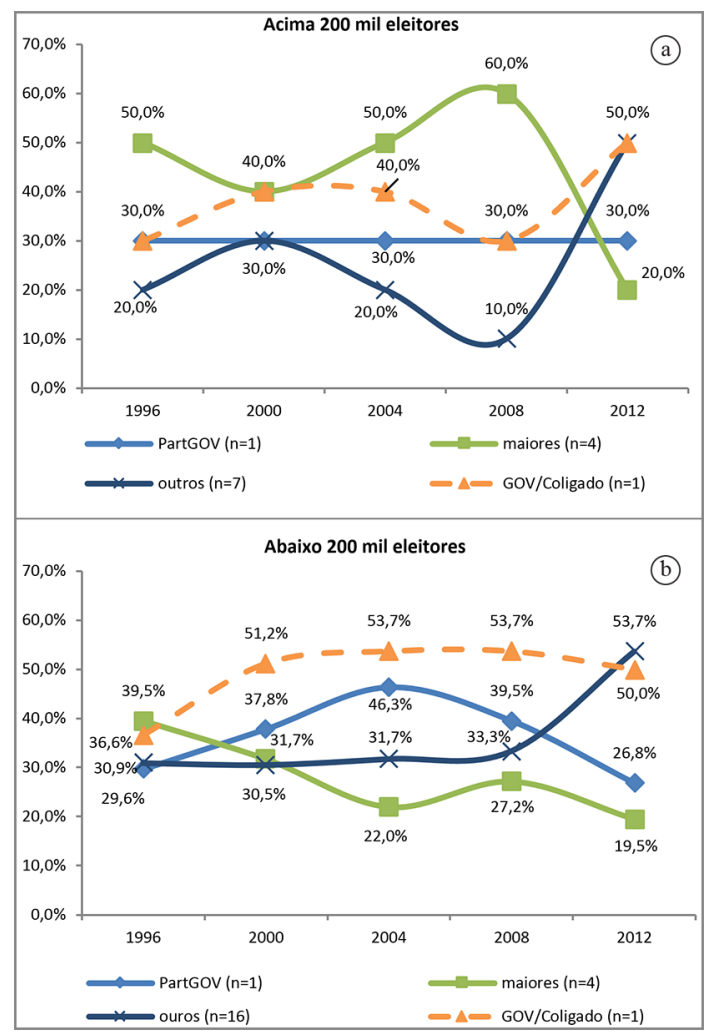

Gráficos 1. (a) e (b). Sucesso eleitoral Partidário (Abaixo e Acima de 200 mil eleitores). Fonte: Gráficos elaborados pelos autores com base em dados do TSE e TRE-RJ (BRASIL, 2014).

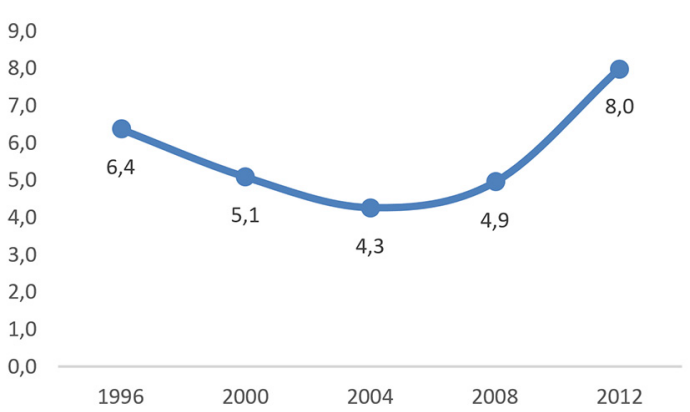

Gráfico 2. NEP Prefeituras Rio de Janeiro (1992 a 2012). Fonte: Gráfico elaborado pelos autores com base em dados do TSE e TRE-RJ (BRASIL, 2014).

\section{Eleições Open Seat}

A produção acadêmica, especialmente a norte-americana, observa as diferentes estratégias dos competidores de acordo com as características da corrida eleitoral (LEVITT, 1994). Neste sentido, concordamos com Barreto (2009, p. 100), quando o mesmo afirma que "[...] pleitos nos quais o chefe do executivo concorre à 


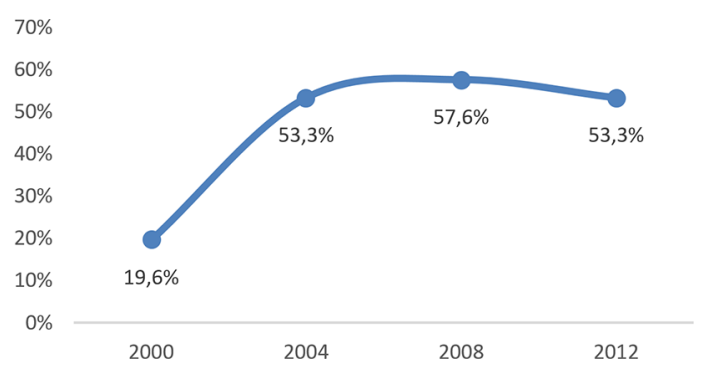

Gráfico 3. Taxa de eleições Open Seat. 2000 a $2012^{11}$. Fonte: Gráfico elaborado pelos autores com base em dados do TSE e TRE-RJ (BRASIL, 2014).

reeleição são institucionalmente diferentes daqueles em que necessariamente há mudança." Considerando esta observação, passamos a verificar como a alteração da regra sobre a reeleição para cargos executivos pôde influenciar as disputas municipais no Rio de Janeiro.

No Gráfico 3 vimos a menor incidência de disputas open seat, aquelas em que não há um candidato buscando a reeleição, na campanha de 2000 , contabilizando $19,6 \%$ das prefeituras. No entanto, este quadro se altera nos pleitos seguintes, estabilizando-se em torno dos $50 \%$. Isto indica que ultimamente cerca de metade dos municípios produziram eleições onde havia ao menos um candidato com reconhecido capital político elevado: o incumbent. Portanto, o suposto que levantamos é que as eleições open seat podem maximizar a força política do governador. A ausência de incumbents eliminaria dessa forma uma significativa variável explicativa para o sucesso eleitoral, abrindo terreno ao governante estadual que poderia tentar preencher esta lacuna. Na próxima seção realizaremos os testes de associação estatística para avaliar esta hipótese.

Outro aspecto importante é o fato das eleições de 2000 terem sido emblemáticas, pois foram as primeiras habilitadas com a reeleição em âmbito local. Como este dispositivo não existia no pleito anterior ${ }^{12}$, ocasião na qual os prefeitos escolheram seus sucessores, houve um sistemático realinhamento dos interesses de elites políticas. Esta regra incentivou, especialmente em 2000, embates eleitorais semelhantes em inúmeras cidades brasileiras, quando antigos padrinhos políticos enfrentaram seus "afilhados", alterando, dessa maneira, a trajetória política das eleições subsequentes.

\footnotetext{
${ }^{11}$ Não consideramos a eleição de 1996 na série histórica pelo fato da mesma não estar habilitada com a reeleição para cargos executivos.

12 A Emenda Constitucional 16 foi aprovada em 05 de junho de 1997 e já valeu para a eleição presidencial de 1998, bem como, para as campanhas municipais de 2000
}

\section{Coligações, alianças nacionais e ideologia}

Sobre as causas que levam os partidos a estabelecer alianças, Soares $(1964,2001)$ formulou duas teorias referenciais na ciência política. Uma, denominada como "resistência ideológica", assenta-se sobre fatores sociológicos, tais como a urbanização e educação, que constrangeriam a formação de coligações entre partidos de diferentes ideologias (PEIXOTO, 2010). Outra, chamada de "economia de esforços", aborda como as regras institucionais, principalmente as eleitorais, restringem o cálculo racional dos partidos, caracterizados por maximizar seu desempenho eliminando custos (PEIXOTO, 2010). Mais recentemente pesquisas procuram observar os níveis de consistência ideológica, ou mesmo de coesão governista, das coligações eleitorais (SCHMITT, 1999; KRAUSE, 2006).

Neste sentido, cremos ser necessário, no intuito de analisar o grau de coerência das alianças partidárias no estado, ampliar o número de agremiações observadas. A julgar que, até o momento, apenas examinamos as coligações praticadas pelo partido governante. Para este objetivo, consideramos as principais legendas nacionais que igualmente seriam relevantes no contexto subnacional: PMDB, PDT, PSDB, PFL/DEM, PT e PSB.

Definimos dois blocos partidários de acordo com as coalizões nacionais. Para as eleições de 1996 e 2000 consideramos: I) bloco governista: PSDB, PFL/DEM e PMDB; e II) bloco oposicionista: PT, PDT e PSB. Na eleição de 2004 apenas invertermos os lados, uma vez que foi a primeira disputa municipal sob nova coalizão, em razão de 2002 o presidente Lula (PT) ter sido eleito: I) bloco governista: PT, PDT e PSB; e II) bloco oposicionista: PSDB, PFL/DEM e PMDB ${ }^{13}$. Para as eleições de 2008 e 2012, deslocamos o PMDB para o bloco governista, já que o partido passou a integrar a base do governo federal: I) bloco governista: PT, PDT, PSB e PMDB; e II) bloco oposicionista: PSDB e PFL/DEM.

Para calcularmos a variável, consideramos uma coligação "Não Consistente" aquela na qual ao menos dois partidos de blocos diferentes a integrem. Por exemplo, se na eleição de 2000 um candidato a prefeito estivesse coligado em sua chapa majoritária tanto com o PT, quanto com o PMDB, consideraríamos esta aliança como "não consistente"14. Dessa forma, acreditamos ter conseguido mensurar a coerência

\footnotetext{
13 Nesta eleição, embora não seja totalmente correto afirmar que o PMDB estivesse na oposição federal em 2004, decidimos por deixar o PMDB em bloco oposto ao PT, pois o alinhamento entre os dois partidos na coalizão governista ocorreu de maneira mais orgânica no segundo mandato do presidente Lula.

$14 \mathrm{Na}$ literatura encontramos indicadores mais sofisticados como, por exemplo, o Índice de Viés Ideológico (MIGUEL; MACHADO, 2007). Entretanto, optamos por este modo simplificado por julgarmos mais adequado para as pretensões do presente artigo.
} 
das alianças municipais em relação ao alinhamento partidário nacional, particularmente entre as eleições de 1996 e 2004, quando a coalizão governista federal era ideologicamente mais uniforme. Com respeito às campanhas de 2008 e 2012, dado o deslocamento do PMDB para o bloco governista, realmente a variável nestes dois pleitos perde em consistência ideológica. Mesmo assim, preferimos manter desta maneira para enfatizar a ordem partidária nacional. Além disso, a aproximação entre PT e PMDB nos municípios, particularmente nos de menor porte, já era evidente mesmo antes dos petistas vencerem a corrida presidencial (PEIXOTO, 2010). Posto que, gradativamente houve uma flexibilização ideológica das coligações petistas, ingressando de maneira irrestrita no "mercado geral" das coligações (RIBEIRO, 2010). Sendo assim, a literatura já tem observado a inconsistência ideológica das alianças, cabendo à variável elaborada no presente artigo enfatizar a consistência da coalizão partidária em nível nacional.

O Gráfico 4 retrata que em 1996 as candidaturas foram muito nacionalizadas, ou seja, com pouco espaço para alianças entre partidos de blocos nacionais diferentes. No entanto, duas eleições depois, em 2004, cerca de dois terços $(66,4 \%)$ das coligações já eram mais inconsistentes. Caso consideremos apenas a capital, desde 1996 todas as alianças apresentaram consistência, não havendo qualquer coligação formada com legendas de blocos nacionais opostos ${ }^{15}$.

Uma explicação plausível para a diminuição da inconsistência no estado é considerar a necessidade dos partidos de esquerda, em particular o PT, de se aliarem ao PMDB para acessar os menores municípios. Como os peemedebistas até 2004 situavam-se em bloco nacional contrário, o aumento de coligações inconsistentes faz sentido. O declínio destas alianças a partir de 2008, por sua vez, igualmente seria justificável, a julgar pelo PMDB já estar integrado formalmente à coalizão governista nacional neste período. A capilaridade dos peemedebistas nos municípios fluminenses, assim como a participação do PT na administração do governador Sérgio Cabral (PMDB), possivelmente esclarecem em muito as maiores taxas de consistência das coligações nas últimas eleições.

\section{Consistência das coligações majoritárias e outras variáveis}

A partir das observações feitas na seção anterior, passamos a examinar a relação entre a consistência das alianças e outras variáveis já abordadas no artigo.

\footnotetext{
15 Sobre estes dados mais detalhados, os mesmos podem ser solicitados aos autores através do correio eletrônico dolandeli@gmail.com
}

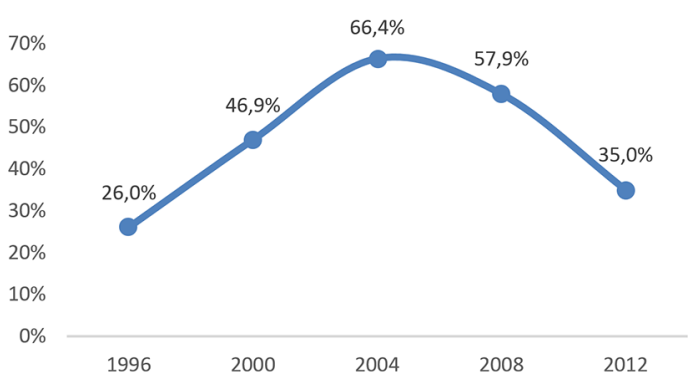

Gráfico 4. Taxa de coligações Não Consistentes. 1996 a 2012. Fonte: Gráfico elaborado pelos autores com base em dados do TSE e TRE-RJ (BRASIL, 2014).

O suposto principal, já retratado na literatura, é que, em razão da falta de incentivo para as elites políticas coordenarem eleições nas menores cidades, as coligações "não consistentes" ocorreriam com maior frequência. Revelando, assim, uma baixa intensidade da organização partidária nessas cidades, diversamente do que ocorre nos principais centros.

Contudo, considerando válida esta assertiva, passam a tomar forma outras hipóteses sobre a racionalidade dos partidos. Primeiramente, como os interesses locais adquirem maior grau de liberdade para maximizar o cálculo eleitoral, uma vez que chapas são formadas por legendas de blocos nacionais distintos, supomos haver forte associação entre voto e inconsistência das coligações. Ou seja, os atores teriam, dessa forma, maior margem para montar alianças voltadas exclusivamente para o êxito eleitoral, não havendo restrições partidárias de outra ordem.

Uma segunda hipótese é o apoio do governador resultar em coligações menos consistentes. Dado que o partido governante consiste em um reconhecido capital político nas disputas municipais, a restrição do alinhamento nacional das agremiações perderia efeito em concorrência ao incentivo local de integrar alianças eleitoralmente fortes.

Por último, supomos que as eleições open seat potencializam a inconsistência das chapas majoritárias. Ao considerarmos que a ausência de prefeitos tentando a reeleição elimina um forte concorrente nos pleitos municipais, acreditamos que os partidos possam flexibilizar suas alianças visando maximizar o sucesso eleitoral.

Para analisar estes supostos, realizamos três testes, que podem ser observados no Quadro 3, também presentes nas seções seguintes: Risco Relativo, Q-Yule e Qui-Quadrado

No primeiro, verificamos as razões de chance (Risco Relativo) da consistência das coligações, dada as características das candidaturas para prefeito. Em segundo lugar, através dos testes Q-Yule, 
Quadro 3. Teste de associação entre variáveis políticas e socioeconômicas e consistência das coligações ${ }^{16}$.

\begin{tabular}{|l|c|c|c|c|c|c|}
\hline \multirow{2}{*}{ Eleições } & \multicolumn{5}{c|}{ Não Consistente } & \multirow{2}{*}{$\boldsymbol{p}$-value } \\
\cline { 2 - 6 } & $\mathbf{Q}_{\mathbf{x y}}$ & $\boldsymbol{p}$-value & $\mathbf{R R}$ & $\boldsymbol{p}$-value & $\chi^{\mathbf{2}}$ & \\
\hline Eleitos & 0,0684 & 0,061 & 0,8 & 0 & 1,2 & 0 \\
GOV & 0,0846 & 0,063 & 0,5 & 0 & 1,8 & 0 \\
Acima 200 mil & $-0,4937$ & 0,06 & 0,2 & 0,01 & 50,06 & 0,01 \\
Open Seat & 0,0134 & 0,057 & 0,6 & 0 & 0,56 & 0 \\
\hline
\end{tabular}

Fonte: Quadro elaborado pelos autores com base em dados do TSE e TRE-RJ (BRASIL, 2014).

examinamos a intensidade, assim como a direção, da associação entre as variáveis. Por último, o teste Qui-Quadrado mostra se a distribuição entre as variáveis possui alguma diferença estatística significativa, levando-nos a rejeitar ou não a hipótese nula (CERVI, 2013).

Dentre as variáveis analisadas neste quadro, apenas a magnitude do distrito apresentou uma associação mais forte, embora negativa $(-0,4937)$. Isso confirma a hipótese de maior consistência das alianças em grandes cidades, pelo menos naquelas acima de $200 \mathrm{mil}$ habitantes. Por sua vez, o sucesso eleitoral $(0,0684)$, o apoio do governador $(0,0846)$, assim como as eleições open seat $(0,0134)$, não apresentaram coeficientes que indicassem qualquer correlação com o nível de consistência das coligações.

Assim, o tamanho das cidades acabou importando mais do que as variáveis políticas, que sustentavam as hipóteses sobre o cálculo racional dos partidos. Vimos, por exemplo, que flexibilizar as alianças não significou necessariamente maior sucesso eleitoral. Da mesma forma, a ausência de incumbents, ou mesmo a presença do partido governante em uma coligação, ambos elementos que, a priori, supomos alterar o cálculo dos atores nas disputas municipais, não influenciaram os níveis de nacionalização ou de coerência das alianças.

Entretanto, é necessário destacar que a magnitude do distrito eleitoral carrega consigo inúmeros fatores relevantes, tais como a urbanização, níveis de escolarização, a questão metropolitana, ou mesmo maiores recursos orçamentários disponíveis, que ao serem omitidos podem enviesar os testes de associação. Assim, ao invés de trazer respostas, deixamos uma questão em aberto. Quais variáveis específicas dos grandes centros, para além do aspecto populacional, que tornam o comportamento das elites políticas tão diferente das demais cidades? Dessa forma, a "teoria da resistência ideológica” de Soares (1964, 2001),

\footnotetext{
16 É importante observar que as variáveis categóricas foram testadas em pares, não havendo interação entre elas a exemplo dos modelos de regressão logística.
}

quanto à exploração de fatores socioeconômicos, provavelmente faça mais sentido sobre a formação de alianças, pelo menos em consideração à séria histórica observada nesta seção.

\section{Sucesso eleitoral e partido governante}

Até aqui descrevemos a performance dos partidos nas eleições. No entanto, não examinamos ainda a intensidade da relação entre o peso político do mandatário estadual e o desempenho eleitoral dos candidatos. A seguir realizaremos estes testes.

No Quadro 4, verificamos que a associação foi positiva forte $(0,6443)$ entre os competidores apoiados pelo governador e o êxito eleitoral, considerando os testes de variáveis binárias Q-Yule $\left(\mathrm{Q}_{\mathrm{xy}}\right)$. Porém, observando cada eleição individualmente, encontramos intensidades diferentes. Na eleição de 1996, por exemplo, a associação foi positiva, embora moderada $(0,4675)$. Índices maiores foram encontrados nas eleições de 2004 e 2008, quando sinalizaram uma associação positiva muito forte, evidenciada pelos respectivos valores dos coeficientes 0,7155 e 0,713 .

Já o teste de Risco Relativo (RR) nos diz que entre os candidatos eleitos de 1996 a 2012 houve 2,3 vezes mais chances de terem sido apoiados pelo governador do que por outras legendas. A exemplo do teste Q-Y, este valor foi menos intenso em $1996(1,7)$ do que em $2004(2,7)$ e $2008(2,6)$.

Por último, os valores do teste Qui-Quadrado indicam que a probabilidade dos dois grupos (GOV e Eleitos) serem distribuídos ao acaso é estatisticamente nulo. Ou seja, as variáveis estão fortemente relacionadas e não são independentes. Novamente, os valores mais significativos foram encontrados para as eleições de $2004(47,4)$ e $2008(41,9)$, enquanto que para 1996 o resultado foi o menor da série histórica $(15,1)$.

Um caminho para compreender os desníveis de associação entre voto e apoio político do governador ao longo das eleições seria observar a avaliação popular 
Quadro 4. Testes de Associação entre Partido do Governador e Eleitos ${ }^{17}$.

\begin{tabular}{|c|c|c|c|c|c|c|}
\hline GOV & \multicolumn{7}{|c|}{ Eleitos } \\
\hline Eleições & $\mathbf{Q}_{\mathbf{x y}}$ & $\boldsymbol{p}$-value & $\mathbf{R R}$ & $\boldsymbol{p}$-value & $\chi^{\mathbf{2}}$ & $\boldsymbol{p}$-value \\
\hline Todas & 0,6443 & 0,036 & 2,3 & 0,026 & 172,4 & 0,026 \\
1996 & 0,4675 & 0,1 & 1,7 & 0,01 & 15,1 & 0,01 \\
2000 & 0,6172 & 0,083 & 2,1 & 0,024 & 31,1 & 0,024 \\
2004 & 0,7155 & 0,067 & 2,7 & 0,036 & 47,4 & 0,036 \\
2008 & 0,713 & 0,071 & 2,6 & 0,038 & 41,9 & 0,038 \\
2012 & 0,672 & 0,075 & 2,4 & 0,029 & 39,3 & 0,03 \\
\hline
\end{tabular}

Fonte: Quadro elaborado pelos autores com base em dados do TSE e TRE-RJ (BRASIL, 2014).

da administração pública. Em 1996, por exemplo, os coeficientes foram os menores $(0,4675)$, justamente durante o governo Marcello Alencar (PSDB), que desistiu de tentar a reeleição por conta dos altos índices de rejeição ${ }^{18}$. Semelhante impopularidade foi encontrada no segundo governo de Sérgio Cabral (PMDB). O mesmo renunciou ao final do mandato para que seu vice, Luiz Fernando Pezão, pudesse assumir e aumentar as chances de sucessão ${ }^{19}$.

No entanto, é preciso observar com maior cuidado o papel das pesquisas de opinião. Na campanha de 2000, o governador Garotinho (PDT) desfrutava de alta popularidade ${ }^{20}$, mas os coeficientes Q-Y de seu apoio às chapas majoritárias municipais $(0,6172)$ ficaram abaixo dos índices calculados para a eleição de 2012, correspondentes ao segundo governo de Sérgio Cabral $(0,672)$. Em outras palavras, o carisma de Garotinho, por si só, não foi suficiente para impulsionar um enraizamento partidário superior ao obtido por Cabral (PMDB), que era comparativamente menos popular.

Esta observação nos indica que outros fatores relevantes provavelmente foram omitidos nos testes realizados. A seguir trataremos desta questão utilizando uma terceira variável interveniente nas associações Q-Y (Qxy:t).

\footnotetext{
17 Aqui agregamos os candidatos do partido do governador e também os apoiados por ele, conforme retratado na variável "GOV/Coligado" dos Gráficos 1 e 2. Para consulta destes dados e de todos os testes a seguir, podemos encaminhar o banco utilizado na pesquisa se solicitado pelo correio eletrônico dolandeli@gmail.com

18 Em dezembro de 1997 a pesquisa de avaliação da administração do governador do Rio de Janeiro, Marcello Alencar (PSDB), realizada pelo Datafolha indicava apenas $21 \%$ de aprovação. No ano seguinte, segundo o mesmo instituto, a nota atribuída pelos cidadãos era de apena 4,7, uma das mais baixas do país.

19 Segundo o Datafolha, a nota atribuída ao governador Sérgio Cabral (PMDB) em novembro de 2010 era 6,8. Em julho de 2013, ainda sob efeito das manifestações de junho, a nota caiu significativamente para 4,9 , quando apenas $25 \%$ dos entrevistados aprovavam a administração. Seguindo assim até a sua renúncia em abril de 2014 .

20 A nota atribuída pelo Datafolha ao governador Garotinho em 2000 era de 7,2 .
}

Quadro 5. Testes de Associação entre Partido do Governador e Eleitos, com uma terceira variável. Eleição de 1996 a $2012^{21}$.

\begin{tabular}{|l|c|c|}
\hline \multicolumn{1}{|c|}{ Associação } & Qxy & p-value \\
\hline \multicolumn{1}{|c|}{ GOV x Eleitos } & $\mathbf{0 , 6 4 4 3}$ & $\mathbf{0 , 0 3}$ \\
\hline Intervenientes & Qxy:t \\
Acima 200 mil eleitores & $\mathbf{0 , 9 0 1 9}$ \\
N. Consistente & 0,7283 \\
Open Seat & 0,7019 \\
\hline
\end{tabular}

Fonte: Quadro elaborado pelos autores com base em dados do TSE e TRE-RJ (BRASIL, 2014).

No Quadro 5 analisamos se a magnitude do distrito eleitoral, a consistência das coligações e as eleições open seat, variáveis retratadas nas seções anteriores, afetaram ou não o grau de associação já calculado no Quadro 4 entre sucesso eleitoral dos candidatos a prefeito e o apoio do governador. Para verificar os dados em detalhe, analisar o Gráfico A1.

Os coeficientes encontrados para as coligações consistentes $(0,7283)$ e eleições open seat $(0,7019)$ apresentaram valores muito próximos aos da associação principal entre governador e prefeitos eleitos $(0,6443)$, não alterando a sua intensidade. Por outro lado, a magnitude do distrito eleitoral foi a única variável que ofereceu algum grau de influência sobre esta relação. Ou seja, a associação positiva forte $(0,6443)$ entre governo estadual e a eleição dos prefeitos seria mais intensa nas cidades acima de 200 mil eleitores. Isto significa que para os eleitos a aliança com o executivo estadual foi mais decisiva nos maiores centros do que nos municípios menores, contradizendo uma hipótese recorrente de que a rede clientelista determina a política local. Era de se esperar o inverso, tendo em vista o alto grau de dependência municipal por recursos, particularmente nas cidades de menor porte.

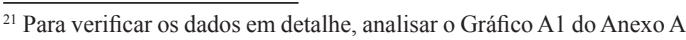


Contudo, sugerimos outra hipótese. Em face das agremiações tenderem a lançar candidatos em cidades acima de 200 mil eleitores, os testes de associação expressam o melhor desempenho da legenda do governador (e das coligações que integra) em meio a um cenário no qual os partidos, especialmente os mais competitivos, estão demasiadamente fracionados. Por este motivo, o peso do partido governante se dilui nas alianças mais amplas, características dos municípios menores, e se sobressai nas maiores cidades, delineadas pela fragmentação. Deste ponto de vista, faz todo sentido a estratégia adotada pelo PMDB fluminense, por exemplo, de abrir mão da cabeça de chapa em muitos municípios menores na eleição de 2012. A legenda apostou nas coligações eleitorais de aliados fortes para manter sua elevada presença nas administrações locais.

A tomar este suposto como válido, passaríamos a reconhecer que o custo de coordenação política dos partidos, inclusive o do próprio governador, realmente seria muito alto nas cidades menores. Da mesma forma, seria pertinente notar a maior autonomia da dinâmica local face à crescente fragmentação partidária. Até mesmo porque, a competitividade dos atores, ou seja, a posição estratégica das legendas na política local, poderia ser mais preponderante para explicar coligações do que os próprios níveis de competição do sistema em si (PEIXOTO, 2010). Assim, verificamos cada vez mais a importância de se analisar os níveis de organização partidária nos municípios, se seriam diretórios constituídos ou comissões provisórias, por exemplo, denotando os seus graus de autonomia política.

\section{A trajetória eleitoral dos candidatos}

Na presente seção passamos a analisar as características dos candidatos quanto ao seu capital político. Neste sentido, além de distingui-los entre incumbents e desafiantes, sugerimos a seguinte categorização das variáveis: a) Desafiante Novo (quando o candidato não participou de nenhuma eleição para prefeito anterior); b) Desafiante Forte (quando o candidato já foi prefeito ou teve boa votação em eleições anteriores); c) Desafiante Fraco $^{22}$ (quando o candidato participou de eleições anteriores mas obteve fraco desempenho ${ }^{23}$ ); e d) Incumbents (os atuais prefeitos que buscam a reeleição).

\footnotetext{
22 Tanto para Desafiante Novo, quanto para Desafiante Fraco, consideramos "boa votação" quando o candidato foi "efetivo" eleitoralmente. Para calcular a efetividade dos candidatos utilizamos a fórmula de fragmentação partidária (NEP) de Laakso e Taagepera (1979), já descrito na nota de rodapé 10 . Este índice é utilizado para identificar o número de partidos efetivos em uma eleição, mas neste caso a usamos para calcular o número de candidatos efetivos nas campanhas para prefeito.

23 Um aspecto não trabalhado neste artigo foi a influência do prefeito impedido pela legislação de se reeleger por já possuir dois mandatos consecutivos. Neste caso, seria importante analisar futuramente o apoio de ex-prefeitos aos novos desafiantes, controlando a sua efetividade.
}

No Gráfico 5 retratamos a distribuição dos tipos de candidaturas nos municípios do Rio de Janeiro. Vimos que grande parte dos competidores são novos, provavelmente pela crescente fragmentação partidária. Notamos também como um desempenho ruim nas eleições majoritárias inviabiliza candidaturas futuras, uma vez que a taxa de desafiantes fracos ficou em torno apenas dos $4 \%$. Situação diferente da dos desafiantes fortes que corresponderam entre $20 \%$ e $30 \%$ dos candidatos. A seguir, observaremos a intensidade da relação entre os tipos de candidaturas e o sucesso eleitoral.

Em primeiro lugar, encontramos no Quadro 6 uma associação positiva forte $(0,6973)$ entre os candidatos serem Incumbents e o sucesso eleitoral, havendo também uma relação positiva moderada no caso dos desafiantes fortes $(0,3348)$. Por outro lado, vimos uma associação negativa forte entre Desafiantes Novos e Desafiantes Fracos, respectivamente-0,6213 e-0,6105. Os testes Q-Y, em si, não revelaram surpresas sobre o que esperar das competições políticas nos municípios.

Quanto ao teste de Risco Relativo (RR), o mesmo nos diz que entre os eleitos de 2000 a 2012 no Rio de Janeiro houve 2,2 vezes mais chances de terem sido Incumbents do que outros tipos de candidatos.

Finalmente, o teste Qui-Quadrado sugere que a probabilidade, tanto dos Desafiantes Fracos, quanto dos Novos, de ter sido distribuída ao acaso foi estatisticamente nula. Em comparação aos valores encontrados para Incumbents e Desafiantes Fortes, respectivamente 10,6 e 26,8, os coeficientes para Desafiantes Fracos e Novos, 129,6 e 129,2, foram muito superiores. Isto pode significar que o baixo desempenho eleitoral destes dois últimos tipos de desafiantes já estaria bem evidenciado pelas suas próprias trajetórias políticas, enquanto que para Incumbents e Desafiantes Fortes outras variáveis importantes possivelmente estão omitidas.

Desta forma, no Quadro 7 buscamos testar a associação entre o êxito nas eleições e os tipos de candidaturas, agregando uma terceira variável interveniente, a exemplo do que já realizamos no Quadro 5.

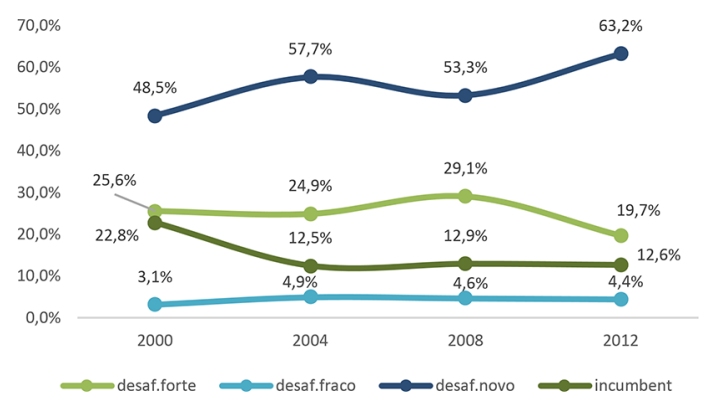

Gráfico 5. Tipos de Candidatos a Prefeito. 2000 a 2012. Fonte: Gráfico elaborado pelos autores com base em dados do TSE e TRE-RJ (BRASIL, 2014). 
Quadro 6. Teste de associação entre competidores e eleitos.

\begin{tabular}{|l|c|c|c|c|c|c|}
\hline \multicolumn{1}{|c|}{ Competidores } & \multicolumn{7}{c|}{ Eleitos } \\
\hline \multicolumn{1}{|c|}{ Todas Eleições } & $\mathbf{Q}_{\mathbf{x y}}$ & $\boldsymbol{p}$-value & $\mathbf{R R}$ & $\boldsymbol{p}$-value & $\chi^{\mathbf{2}}$ & $\boldsymbol{p}$-value \\
\hline Incumbents & 0,6973 & 0,041 & 2,2 & 0,025 & 10,6 & 0,002 \\
DesafianteForte & 0,3348 & 0,06 & 1,2 & 0,005 & 26,8 & 0,005 \\
DesafianteFraco & $-0,6105$ & 0,148 & 0,2 & 0,002 & 129,6 & 0,025 \\
DesafianteNovo & $-0,6213$ & 0,041 & 0,2 & 0,024 & 129,2 & 0,025 \\
\hline
\end{tabular}

Fonte: Quadro elaborado pelos autores com base em dados do TSE e TRE-RJ (BRASIL, 2014).

Quadro 7. Testes de Associação entre Tipos de Candidaturas e Eleitos, com uma terceira variável. Eleição de 2000 a $2012^{24}$.

\begin{tabular}{|l|c|c|c|c|c|}
\hline \multicolumn{3}{|c|}{ Associação } & \multicolumn{3}{c|}{ Intervenientes (Qxy:t) } \\
\hline & Qxy & p-value & $\begin{array}{c}\text { Acima 200 mil } \\
\text { eleitores }\end{array}$ & N. Consistente & GOV \\
\hline Incumbents x Eleitos & 0,6973 & 0,041 & 0,9333 & 0,7553 & 0,7406 \\
Desaf.Forte x Eleitos & 0,3348 & 0,06 & 0,8335 & 0,3925 & 0,4667 \\
Desaf.Novo x Eleitos & $-0,6213$ & 0,041 & 0,6211 & $*$ & $-0,087$ \\
Desaf.Fraco x Eleitos & $-0,6105$ & 0,148 & 0,5055 & $*$ & 0,2327 \\
\hline
\end{tabular}

* valores inconsistentes. Fonte: Quadro elaborado pelos autores com base em dados do TSE e TRE-RJ (BRASIL, 2014).

Os testes indicam que as coligações não consistentes e o apoio do governador não influenciaram na relação entre voto e tipos de candidaturas. De maneira diferente, a competição nas cidades maiores teve efeito positivo sobre o sucesso eleitoral, especialmente em se tratando de Incumbents e Desafiantes Fortes. Ou seja, prefeitos buscando reeleição ou candidatos com histórico de boa votação têm suas chances de vitória aumentar nas grandes cidades. Assim, para além da visibilidade política proporcionada pelos maiores distritos, parece ser justificado o esforço dos partidos de lançar candidatos nestas cidades quando os mesmos possuem potencial eleitoral. Para verificar os dados em detalhe, analisar os Gráficos A2 a A5.

Com respeito aos novos e fracos desafiantes, as cidades maiores também influenciaram a sua relação com o sucesso. Como para estes dois tipos de competidores a associação com o voto foi negativa, nos municípios acima de 200 mil eleitores o desempenho deles tendeu a piorar. Em outras palavras, o custo de lançar candidatos fracos e inexperientes nas menores cidades é alto demais para os partidos competitivos, ainda mais nestes contextos onde inexiste a compensação por maior projeção política, restando apenas os interesses locais como mobilizadores de candidaturas.

Por sua vez, supomos que para os pequenos e novos partidos esta interpretação perde força. Como as legendas recém-criadas, muito comuns no quadro

\footnotetext{
${ }^{24}$ Para verificar os dados, analisar os Gráficos A2 a A5.
}

multipartidário atual, não possuem qualquer custo de coordenação, as mesmas suprem demandas locais dando espaço a candidatos que possivelmente seriam inviáveis no passado, quando a oferta partidária era menor.

Um fato que não pode passar despercebido é o apoio do governador não influenciar a relação entre os tipos de candidaturas e a votação. Isso mostra como a dinâmica local possui mais autonomia do que se pensa.

\section{Migração partidária de prefeitos}

Apesar de considerarmos o suposto da reprodução do presidencialismo de coalizão em nível subnacional, era de se esperar uma migração moderada de prefeitos para o partido do governador, uma vez que a busca por recursos supúnhamos ocorrer de maneira mais intensa nos estados mais pobres da federação. Entretanto, a despeito do Rio de Janeiro ser dono do segundo maior PIB nacional, atrás apenas de São Paulo, a infidelidade partidária em determinados momentos foi elevada.

Em geral, o quadro eleitoral no estado é marcado por candidatos que se apresentaram apenas uma única vez: foram 775 , quase $70 \%$ do total de 1.137 candidatos. Entretanto, de acordo com a Tabela 1, dentre aqueles que se reapresentaram, é notável a característica da migração, posto que, mais da metade trocou ao menos uma vez de partido.

Este quadro não se altera quando observamos apenas os eleitos, conforme descrição da Tabela 2. 
Tabela 1. Candidatos e migração partidária (eleições de 1996 a 2012).

\begin{tabular}{|c|c|c|c|c|c|c|c|c|}
\hline \multirow{2}{*}{$\begin{array}{c}\text { Qtde } \\
\text { Partidos }\end{array}$} & \multirow{2}{*}{$\begin{array}{l}\text { Única } \\
\text { Eleição }\end{array}$} & \multicolumn{6}{|c|}{ Mais de uma Eleição } & \multirow{2}{*}{ Total } \\
\hline & & 2 & 3 & 4 & 5 & Subtotal & $\%$ & \\
\hline 1 & 775 & 111 & 28 & 15 & 2 & 156 & 43,1 & 931 \\
\hline 2 & - & 99 & 51 & 11 & 1 & 162 & 44,8 & 162 \\
\hline 3 & - & 0 & 30 & 11 & 2 & 43 & 11,9 & 43 \\
\hline 4 & - & 0 & 0 & 0 & 1 & 1 & 0,3 & 1 \\
\hline Soma & 775 & 210 & 109 & 37 & 6 & 362 & 100 & 1137 \\
\hline
\end{tabular}

Fonte: Tabela elaborada pelos autores com base em dados do TSE e TRE-RJ (BRASIL, 2014).

Tabela 2. Prefeitos eleitos e migração partidária (eleições de 1996 a 2012).

\begin{tabular}{cccccccc}
\hline Qtde & Único & \multicolumn{5}{c}{ Mais de um mandato } & Total \\
\cline { 3 - 7 } Partidos & Mandato & $\mathbf{2}$ & $\mathbf{3}$ & $\mathbf{4}$ & Subtotal & $\mathbf{\%}$ & \\
\hline 1 & 162 & 55 & 6 & 0 & 223 & 74,8 & 223 \\
2 & - & 59 & 10 & 1 & 70 & 23,5 & 70 \\
3 & - & 0 & 4 & 1 & 5 & 1,7 & 5 \\
Soma & 162 & 114 & 20 & 2 & 298 & 100 & 298 \\
\hline
\end{tabular}

Fonte: Tabela elaborada pelos autores com base em dados do TSE e TRE-RJ (BRASIL, 2014).

Embora sejam 458 eleições, entre 1996 e 2012, somente 298 políticos se elegeram, uma vez que muitos foram reeleitos ou mesmo governaram mais de uma cidade. De qualquer forma, identificamos uma tendência à migração daqueles políticos que ficaram mais tempo no poder. Por exemplo, nenhum dos prefeitos com quatro mandatos manteve-se no mesmo partido. Estas lideranças locais aparentemente movimentaram-se sem qualquer constrangimento que uma troca de partido poderia proporcionar. Tal dinâmica foi observada por Dantas $(2009$, p. 8) como um dos fenômenos que mais ocorreram antes da decisão do judiciário sobre a infidelidade partidária.

A partir desta constatação, detalharemos como o movimento migratório ocorreu em torno do partido governante. Nos próximos quadros, as colunas "Destino" indicam a situação dos prefeitos eleitos pela legenda do governador na campanha anterior, mostrando a permanência deles ou não na organização. Já as colunas "Origem" assinalam a trajetória anterior dos incumbents candidatos pela agremiação do governador. Assim, verificaremos o poder de atração do executivo estadual sobre prefeitos que buscam a reeleição.

No Quadro 8, vimos que em 2000, poucos prefeitos do PSDB trocaram de partido. A maioria continuou na legenda $(40,7 \%)$, mas boa parte não se candidatou (25,9\%). Apenas 2 prefeitos do PSDB migraram para o PDT, o então partido governante. Os pedetistas, por outro lado, receberam um incremento de 8 prefeitos, correspondendo à metade das prefeituras no qual defendiam seus mandatos. Estes dados sugerem que a agremiação do governador em 2000 (PDT) obteve um reforço considerável de incumbents para suas fileiras.

Mais uma vez lembramos que esta primeira campanha municipal habilitada com o dispositivo da "reeleição" foi um processo de realinhamento de elites. Neste sentido, é provável que a migração fosse mais arriscada, uma vez que ex-prefeitos, "padrinhos" políticos de muitos incumbents, disputariam o pleito. Dessa forma os mandatários locais podem ter optado por maior estabilidade em seus respectivos grupos partidários. Além disso, incentivos federais possivelmente pesaram no cálculo eleitoral destes prefeitos na eleição de 2000, pois o PSDB estava à frente do segundo mandato presidencial de Fernando Henrique Cardoso. Contudo, o desempenho dos tucanos fluminenses foi fraco: venceram em apenas 11 prefeituras, sendo 7 reeleições. Um declínio considerável em comparação ao pleito anterior quando governavam o estado e elegeram 27 prefeitos.

Na eleição municipal seguinte, verificamos no Quadro 9 que das 34 prefeituras conquistadas no pleito anterior pelo PDT, apenas uma permaneceu com os pedetistas. $\mathrm{O}$ destino preferencial foi o mesmo do ex-governador Anthony Garotinho: o PMDB. Ao todo, 19 prefeitos deixaram o partido. Destes, 14 buscaram a reeleição em 2004 filiados ao PMDB. Esta migração potencializou a força dos peemedebistas nos municípios, dado que apenas 3 prefeitos do total de 25 incumbents 
Quadro 8. Destino e origem dos prefeitos do partido do governador. Eleição 2000.

\begin{tabular}{|c|c|c|c|c|c|}
\hline \multicolumn{3}{|c|}{ Destino PSDB 1996} & \multicolumn{3}{|c|}{ Origem PDT 2000} \\
\hline \multicolumn{3}{|c|}{ Saíram do PartidoGOV anterior } & \multicolumn{3}{|c|}{ Entraram no PartidoGOV atual } \\
\hline PV & 3 & $11,1 \%$ & PSDB & 2 & $12,5 \%$ \\
\hline PDT & 2 & $7,4 \%$ & PL & 2 & $12,5 \%$ \\
\hline PP & 2 & $7,4 \%$ & PMDB & 2 & $12,5 \%$ \\
\hline PTB & 1 & $3,7 \%$ & РPB & 1 & $6,3 \%$ \\
\hline PMDB & 1 & $3,7 \%$ & PFL & 1 & $6,3 \%$ \\
\hline \multicolumn{6}{|c|}{ Permaneceram } \\
\hline PSDB & 11 & $40,7 \%$ & PDT & 8 & $50,0 \%$ \\
\hline \multicolumn{6}{|c|}{ Não se candidataram à reeleição } \\
\hline & 7 & $25,9 \%$ & & & \\
\hline Soma & 27 & $100 \%$ & & 16 & $100 \%$ \\
\hline
\end{tabular}

Fonte: Quadro elaborado pelos autores com base em dados do TSE e TRE-RJ (BRASIL, 2014).

Quadro 9. Destino e origem dos prefeitos do partido do governador. Eleição 2004.

\begin{tabular}{|c|c|c|c|c|c|}
\hline \multicolumn{3}{|c|}{ Destino PDT 2000} & \multicolumn{3}{|c|}{ Origem PMDB 2004} \\
\hline \multicolumn{3}{|c|}{ Saíram do PartidoGOV anterior } & \multicolumn{3}{|c|}{ Entraram no PartidoGOV atual } \\
\hline PMDB & 14 & $41,2 \%$ & PDT & 14 & $56 \%$ \\
\hline PSC & 1 & $2,9 \%$ & PSB & 3 & $12 \%$ \\
\hline PL & 1 & $2,9 \%$ & PSDB & 2 & $8 \%$ \\
\hline PSB & 1 & $2,9 \%$ & PFL & 1 & $4 \%$ \\
\hline PT & 1 & $2,9 \%$ & PMN & 1 & $4 \%$ \\
\hline PPS & 1 & $2,9 \%$ & PP & 1 & $4 \%$ \\
\hline \multicolumn{6}{|c|}{ Permaneceram } \\
\hline PDT & 1 & $2,90 \%$ & PMDB & 3 & $12 \%$ \\
\hline \multicolumn{6}{|c|}{ Não se candidataram à reeleição } \\
\hline & 6 & $17,60 \%$ & & & \\
\hline \multicolumn{6}{|c|}{ Impedidos* } \\
\hline & 8 & $23,5 \%$ & & & \\
\hline Soma & 34 & $100 \%$ & & 25 & $100 \%$ \\
\hline
\end{tabular}

* Impedido de reeleição. Prefeitos no segundo mandato. Fonte: Quadro elaborado pelos autores com base em dados do TSE e TRE-RJ (BRASIL, 2014).

da corrida eleitoral de 2004 pertenciam aos seus quadros partidários na eleição anterior.

Surge, desta maneira, um questionamento. $\mathrm{O}$ que mais importou neste contexto para acentuar a migração partidária, a simples alternância de poder ou a movimentação das lideranças e elites políticas?

Entre as duas eleições, o PDT não havia apenas deixado de administrar o governo estadual, mas sobretudo tinha perdido um quadro político estratégico na política subnacional, acarretando um processo migratório em efeito cascata. Primeiro, Anthony Garotinho trocou o PDT pelo PSB, visando concorrer as eleições presidenciais de 2002, mesmo ano em que sua esposa, Rosinha Garotinho, foi eleita governadora do estado. Em segundo lugar, ambos se filiaram ao PMDB atraindo boa parte dos prefeitos.

A comparação entre as eleições de 2000 e 2004 reforça o argumento de que o deslocamento de elites políticas estratégicas no contexto subnacional parece ter acentuado o fenômeno migratório. Ou seja, os 
incentivos institucionais que permitiam a migração eram determinantes, mas a relevância dos atores intensificou esse processo.

Quanto à campanha municipal de 2008, a mesma se sucedeu com o PMDB novamente à frente do governo estadual. Foram as primeiras disputas para prefeito ocorridas durante o mandato de Sérgio Cabral (PMDB).

Embora o declínio do número de prefeituras do PMDB desde 2004 tenha sido evidente, dado já analisado nas seções anteriores do artigo, desta vez $75 \%$ dos incumbents peemedebistas haviam sido eleitos pela própria legenda, de acordo com o Quadro 10. Além disso, o PMDB ainda recrutou prefeitos de cinco partidos diferentes, perdendo apenas dois para outras agremiações. Sugerindo uma consolidação de seu quadro partidário nos municípios.

No entanto, este cenário mudou na eleição subsequente, realizada durante o segundo mandato peemedebista de Sérgio Cabral.

Apesar do PMDB ter lançado 16 incumbents no pleito de 2012, desta vez não houve qualquer adesão de prefeitos provenientes de outras legendas, conforme descrito no Quadro 11.

Sobre este ponto é preciso destacar que uma resolução do TSE de 2007 disciplinou o processo de perda de cargo eletivo em casos de infidelidade

Quadro 10. Destino e origem dos prefeitos do partido do governador. Eleição 2008.

\begin{tabular}{|c|c|c|c|c|c|}
\hline \multicolumn{3}{|c|}{ Destino PMDB 2004} & \multicolumn{3}{|c|}{ Origem PMDB 2008} \\
\hline \multicolumn{3}{|c|}{ Saíram do PartidoGOV anterior } & \multicolumn{3}{|c|}{ Entraram no PartidoGOV atual } \\
\hline PDT & 1 & $2,4 \%$ & PFL & 1 & $5 \%$ \\
\hline \multirow[t]{4}{*}{ PSDB } & 1 & $2,4 \%$ & PSDB & 1 & $5 \%$ \\
\hline & & & PV & 1 & $5 \%$ \\
\hline & & & PMN & 1 & $5 \%$ \\
\hline & & & PSC & 1 & $5 \%$ \\
\hline \multicolumn{6}{|l|}{ Permaneceram } \\
\hline PMDB & 15 & $36,6 \%$ & PMDB & 15 & $75 \%$ \\
\hline \multicolumn{6}{|c|}{ Não se candidataram à reeleição } \\
\hline & 9 & $22 \%$ & & & \\
\hline \multicolumn{6}{|c|}{ Impedidos* } \\
\hline & 15 & $36,6 \%$ & & & \\
\hline Soma & 41 & $100 \%$ & & 20 & $100 \%$ \\
\hline
\end{tabular}

* Impedido de reeleição. Prefeitos no segundo mandato. Fonte: Quadro elaborado pelos autores com base em dados do TSE e TRE-RJ (BRASIL, 2014).

Quadro 11. Destino e origem dos prefeitos do partido do governador. Eleição 2012.

\begin{tabular}{|c|c|c|c|c|c|}
\hline \multicolumn{3}{|c|}{ Destino PMDB 2008} & \multicolumn{3}{|c|}{ Origem PMDB 2012} \\
\hline \multicolumn{3}{|c|}{ Saíram do PartidoGOV anterior } & \multicolumn{3}{|c|}{ Entraram no PartidoGOV atual } \\
\hline PR & 1 & $2,9 \%$ & & & \\
\hline \multicolumn{6}{|l|}{ Permaneceram } \\
\hline PMDB & 16 & $45,7 \%$ & PMDB & 16 & $100 \%$ \\
\hline \multicolumn{6}{|c|}{ Não se candidataram à reeleição } \\
\hline & 5 & $14 \%$ & & & \\
\hline \multicolumn{6}{|c|}{ Impedidos* } \\
\hline & 13 & $37,1 \%$ & & & \\
\hline Soma & 35 & $100 \%$ & & 16 & $100 \%$ \\
\hline
\end{tabular}

* Impedido de reeleição. Prefeitos no segundo mandato. Fonte: Quadro elaborado pelos autores com base em dados do TSE e TRE-RJ (BRASIL, 2014). 
partidária ${ }^{25}$. Essa medida além de ter gerado incentivos à fragmentação do sistema partidário, visto que a migração para novas legendas não resulta em cassação do mandato (FREITAS, 2012), parece ter influenciado também as estratégias de recrutamento do partido governante.

Outro fator de ordem conjuntural, da mesma forma, seria pertinente para explicar o declínio no número de prefeituras do PMDB, para além da migração partidária. As eleições de 2012 foram as primeiras disputadas após o rompimento do ex-governador Garotinho com os peemedebistas. Esta cisão política poderia ter enfraquecido a influência do partido em muitos municípios fluminenses.

Em resumo, a decisão do judiciário sobre a infidelidade partidária restringiu a estratégia de renovação de quadros do partido governante. Contudo, também é válido o argumento de que o executivo estadual não precise necessariamente recrutar lideranças locais para a sua própria organização visando apoio político. $\mathrm{O}$ mesmo pode ocorrer de diversas formas, desde a ingerência do governador nas direções partidárias de legendas recém-criadas até mesmo à cooptação por meio de recompensas com cargos na administração pública. Por isso, cremos que as restrições institucionais explicam apenas parte da questão.

A permanência por tempo elevado no poder resulta em um frequente desgaste político de partidos e políticos, situação conhecida na literatura como "lame duck". Dado este cenário, gradativamente os interesses locais se mobilizam para disputar as prefeituras municipais, tendo em vista a característica da carreira política no país ter como prêmio maior o executivo, esfera que administra a maior parte dos recursos públicos. Além disso, os níveis mais elevados de fragmentação partidária recente diminuíram os custos para o lançamento de candidatos pressionando ainda mais este quadro. Enfim, considerando a série histórica observada, a conjunção destes fatores acima comentados provavelmente tenha mudado o rumo das estratégias coligacionistas do partido governante, particularmente o PMDB que ficou mais tempo no poder, no intuito de não perder aliados nos municípios.

\section{Considerações finais}

O presente artigo, seguindo seu propósito de pesquisar as campanhas municipais para prefeito no Rio de Janeiro, identificou, especialmente nas cidades abaixo de 200 mil eleitores, que as agremiações partidárias acompanharam

\footnotetext{
25 A Resolução 22.610 de 2007 do TSE decidiu que partidos podem solicitar a perda do cargo eletivo nos casos de desfiliação partidária sem "justa causa". De acordo com o Art $1^{\circ}$ da resolução, considera-se justa causa "[...] a incorporação ou fusão do partido, a criação de novo partido, a mudança substancial ou o desvio reiterado do programa partidário e a grave discriminação pessoal.”(BRASIL, 2007)
}

a lógica política subnacional. Corroborando de certa forma com os achados referenciais da literatura (LIMA JUNIOR, 1983; DANTAS, 2007, p. 165). Em outras palavras, os partidos na maioria dos casos definiram suas estratégias eleitorais com base na ordem política estadual.

Entretanto, não cremos que os dados analisados eliminem totalmente a relevância da esfera nacional na competição eleitoral local. Se considerarmos apenas as maiores cidades do estado, incluindo a capital carioca, as estratégias partidárias foram substancialmente distintas das demais e enviesadas pelo alinhamento político federal. Assim, destacamos que neste conjunto representado pelas principais cidades do estado vimos o desenrolar das clivagens partidárias mais relevantes da série histórica.

A magnitude do distrito eleitoral, confirmando sua importância tal como já fora destacada na literatura (NICOLAU, 1996), ainda foi significativa para observarmos o grau de influência do partido governante nas eleições municipais. Nos testes de associação estatística constatamos que o apoio do executivo estadual impactou as chances de vitória dos candidatos a prefeito, embora, o mesmo tenha ocorrido em maior grau nas principais cidades.

Sobre os partidos, observamos a hegemonia do PMDB ao longo das últimas eleições, enquanto que PT e PSDB poucas vezes foram protagonistas na política fluminense. Em geral, o partido governante, tal como esperávamos, confirmou seu elevado desempenho nas campanhas municipais. Contudo, os achados deste artigo sugerem uma diluição de sua força eleitoral. Assim, o PMDB, organização que governa o estado desde 2003, declinou em número de prefeituras a cada pleito, abrindo mão de boa parte das candidaturas "cabeça de chapa" em comparação a campanhas anteriores. Em termos metodológicos, a legenda do governador, neste sentido, talvez deixe de ser uma proxy eficiente de governismo para contextos similares aos do Rio de Janeiro.

É importante destacar também que as restrições institucionais recentes atingiram diretamente as estratégias das elites partidárias. A migração de prefeitos, por exemplo, que era responsável por boa parte da renovação de quadros políticos da legenda do governador, foi mitigada em virtude de uma decisão do TSE.

Em se tratando especificamente dos candidatos, da mesma forma constatamos o que já se esperava. Os incumbents tiveram forte associação com o sucesso eleitoral, assim como os desafiantes com trajetória de boas votações. Além disso, mais uma vez o porte do município influenciou positivamente, tendo em vista a maior intensidade eleitoral do capital político dos 
competidores nas cidades acima de 200 mil eleitores. Provavelmente, este achado justifica o maior esforço dos partidos em lançar candidaturas nos grandes centros quando possuem quadros competitivos.

No entanto, a novidade encontrada ficou a cargo da falta de influência entre o apoio do partido governante e a performance tanto de incumbents, quanto de desafiantes fortes. Os governadores, como vimos, estão associados positivamente ao êxito dos candidatos, mas se os mesmos carregam consigo um forte capital político, o apoio do executivo estadual não altera tal desempenho. Isto sugere uma autonomia da dinâmica local, particularmente nos menores municípios, mais intensa do que se supõe, possivelmente caracterizada pelo personalismo, a julgar que as características individuais do candidato se sobressaíram na competição política. Assim, compreender os níveis de organização partidária municipal, considerando a independência política relativa entre os diretórios e comissões provisórias, poderia contribuir para mensurar o suporte organizativo destas fortes lideranças locais. De todo modo, transpor a posição estratégica dos atores nos municípios se torna uma tarefa árdua até mesmo para organizações partidárias estaduais eleitoralmente competitivas.

Fica em aberto, dessa forma, uma questão sobre a capacidade de intervenção das legendas nestes contextos. Considerando válidos os achados sobre a inconsistência das coligações nas menores cidades, não há como deixar de supor que partidos ao liderarem coalizões governamentais duradouras nos estados, em dado momento, encontrarão invariavelmente agremiações ou grupos políticos aliados dispostos a lançar candidaturas próprias. No entanto, longe de representar uma fissura entre dinâmicas políticas locais e alinhamentos partidários estaduais, ou mesmo nacionais, tal comportamento julgamos estar enraizado no fato do poder executivo significar o topo da carreira política brasileira. Assim, apesar de nas últimas eleições o partido governante ter declinado em número de prefeituras, não vimos necessariamente um quadro político de rupturas, mas sim de readequação da estratégia peemedebista visando permanecer influente nos municípios.

Em resumo, o desempenho do PMDB em 2012, a princípio, poderia ter sido típico do partido lame duck, fatigado pelo longo tempo no poder. Entretanto, o que vimos foi um padrão coligacionista mais flexível da legenda do governador, que possivelmente tende a se estabilizar nas próximas eleições, independentemente do partido que estiver no poder estadual. Haja vista, que os constrangimentos e incentivos institucionais recentes do sistema político brasileiro, em particular as restrições quanto à migração partidária, não recomendam cisões políticas nos municípios, caso o governador queira maximizar sua presença localmente.

Assim, o artigo pretendeu ter contribuído com hipóteses e argumentos, apesar do estudo tratar de uma única realidade subnacional, sobre como as coligações eleitorais evidenciam a capacidade das elites políticas, especialmente daquelas que ocupam o centro do poder estadual, de coordenar as organizações partidárias na arena eleitoral.

\section{Referências}

ABRUCIO, F. L. O Ultrapartidarismo estadual. In: ANDRADE, R. C. (Org.). Processo de Governo no Município e no Estado: uma análise a partir de São Paulo. São Paulo: Edusp/FAPESP, 1998.

ALVES, J. E. D. As Eleições municipais de 2004 e o bipartidarismo de coalizão. Rio de Janeiro: Escola Nacional de Ciências Estatísticas/IBGE, 2007.

AMES, B. The reverse coattails effect: local party organization in the 1989 Brazilian presidential election. The American Political Science Review, v. 88, n. 1, p. 95-111, 1994. http://dx.doi.org/10.2307/2944884.

BARRETO, A. A. B. Reeleição para o executivo municipal no Brasil (2000-2008). Revista Debates, v. 3, n. 2, p. 97-115, 2009.

BORGES, A. Rethinking state politics: the Withering of State Dominant Machines. Brazilian Political Science Review, v. 2, p. 108-137, 2007.

BORGES, A. Federalismo, dinâmica eleitoral e políticas públicas no Brasil: uma tipologia e algumas hipóteses. Sociologias, ano 12, n. 24, p. 120-157, 2010.

BRASIL. Tribunal Superior Eleitoral. Resolução 22.610 de 2007, resolve disciplinar o processo de perda de cargo eletivo, bem como de justificação de desfiliação partidária. Diário Oficial [da] República Federativa do Brasil, Brasília, DF, 25 out. 2007. Disponível em: $<$ http://www.tse.jus.br/arquivos/tse-resolucao-22-610 $>$. Acesso em: 03 nov. 2014.

BRASIL. Tribunal Superior Eleitoral. Repositório de dados eleitorais. Brasília, 2014. Disponível em: $<\mathrm{http}: / /$ www.tse.jus.br/eleicoes/estatisticas/repositorio-dedados-eleitorais>. Acesso em: 03 nov. 2014

CARVALHO, J. M. Mandonismo, coronelismo, clientelismo: uma discussão conceitual. Dados, v. 40, n. 2, 1997.

CERVI, E. U. Análise de dados categóricos em ciência política: uso de testes estatísticos em tabelas de contingencia com fontes secundárias de dados. Curitiba: UFPR, 2013.

CORTEZ, R. Eleições majoritárias e entrada estratégica no sistema partidário-eleitoral brasileiro (1990-2006). 2009. 160 p. Tese (Doutorado em Ciência Política)Universidade de São Paulo, São Paulo, 2009. 
DANTAS, H. Coligações em eleições majoritárias municipais: a lógica do alinhamento dos partidos politicos brasileiros nas disputas de 2000 e 2004. 2007. 176 p. Tese (Doutorado em Ciência Política)Universidade de São Paulo, São Paulo, 2007.

DANTAS, H. Coligações nas eleições municipais de 2000 a 2008: a força dos partidos dos governadores. Revista Liberdade e Cidadania, ano 2, n. 6, 2009.

DUVERGER, M. Os partidos políticos. Rio de Janeiro: Zahar Editores, 1970.

FLEISCHER, D. As eleições municipais no Brasil: uma análise comparativa (1982-2000). Opinião Pública, Campinas, v. 8, n. 1, p. 80-105, 2002.

FREITAS, A. Migração partidária na câmara dos deputados de 1987 a 2009. Dados, v. 55, n. 4, p. 951-986, 2012.

KERBAUY, M. T. M. Legislativo municipal, organização partidária e coligações partidárias. Cadernos Gestão Pública e Cidadania, v. 13, n. 53, 2008.

KRAUSE, S. Direita e esquerda: faz diferença? Comparando estratégias de coligações nas eleições das capitais brasileiras em 2004. In: LEMENHE, M. A.; ACCIOLY, C.; VASCONCELOS, R. Política, cultura e processos eleitorais. Rio de Janeiro: Fundação Konrad Adenauer, 2006. p. 27-48.

KRAUSE, S. Coligações: o estado e os desafios da arte. In: KRAUSE, S.; DANTAS, H.; MIGUEL, L. F. Coligações partidárias na nova democracia: perfis e tendências. Rio de Janeiro: Fundação Konrad Adenauer, 2010. p 9-18.

LAAKSO, M.; TAAGEPERA, R. 'Effective' number of parties: a measure with application to West Europe. Comparative Political Studies, v. 12, n. 1, p. 3-27, 1979.

LEAL, V. N. Coronelismo, enxada e voto: o município e o regime representativo no Brasil. 6. impr. São Paulo: Editora Nova Fronteira, 1997.

LEVITT, S. D. Using repeat challengers to estimate the effect of campaign spending on election outcomesin the U.S. house. Journal of Political Economy, v. 102, n. 4, p. 777-798, 1994. http://dx.doi.org/10.1086/261954.

LIMAJUNIOR, L. O. B. Os partidos politicos brasileiros: a experiência federal e regional: 1945-64. Rio de Janeiro: Graal, 1983.

MAINWARING, S. Sistemas partidários em novas democracias: o caso do Brasil. Porto Alegre: Mercado Aberto, 2001.

MAINWARING, S.; MENEGUELLO, R.; POWER, T. Partidos conservadores no Brasil contemporâneo. São Paulo: Paz e Terra, 2000.

MIGUEL, L. F.; MACHADO, C. Um equilíbrio delicado: a dinâmica das coligações do PT em eleições municipais (2000 e 2004). Dados, v. 50, n. 4, p. 757-793, 2007.

MONTERO, A. P. Making and remaking "good government" in Brazil: subnational industrial policy in Minas Gerais. Latin American Politics and Society, v. 43, n. 2, p. 49-80, 2001. http://dx.doi.org/10.2307/3176971.
NICOLAU, J. Multipartidarismo e democracia: um estudo sobre o sistema partidário brasileiro. Rio de Janeiro: Editora Fundação Getúlio Vargas, 1996

NICOLAU, J. Como controlar o representante? Considerações sobre as eleições para Câmara dos Deputados no Brasil. Dados, v. 45, n. 2, 2002.

PANEBIANCO, A. Modelos de Partido: organização e poder nos partidos políticos. São Paulo: Martins Fontes, 2005

PEIXOTO, V. Coligações eleitorais nos municípios brasileiros: uma análise quantitativa. In: Encontro da Associação Brasileira de Ciência Política, 6., 2008, Campinas. Anais... Campinas: ABCP, 2008.

PEIXOTO, V. Coligações eleitorais nos municípios brasileiros: competição e estratégia. In: KRAUSE, S.; DANTAS, H.; MIGUEL, L. F. Coligações partidárias na nova democracia: perfis e tendências. Rio de Janeiro: Fundação Konrad Adenauer, 2010. p. 277-298. PEREIRA, C.; RENNÓ, L. O que é que o reeleito tem? O retorno: o esboço de uma teoria da reeleição no Brasil. Revista de Economia Política, São Paulo, v. 27, n. 4, p. 664-683, 2007.

RIBEIRO, P. F. Velhos e novos companheiros: coligações eleitorais nos municípios do "G79" (1996-2008). In: KRAUSE, S.; DANTAS, H.; MIGUEL, L. F. Coligações partidárias na nova democracia: perfis e tendências. Rio de Janeiro: Fundação Konrad Adenauer, 2010. p. 301-323.

SAMUELS, D. The gubernatorial coat-tails effect: federalism and congressional elections in Brazil. The Journal of Politics, v. 62, n. 1, p. 240-253, 2000. http:// dx.doi.org/10.1111/0022-3816.00012.

SAMUELS, D. Incumbents and challengers on a level playing field: assessing the impact of campaign finance in Brazil. The Journal of Politics, v. 63, n. 2, p. 569584, 2001. http://dx.doi.org/10.1111/0022-3816.00079.

SCHMITT, R. Coligações eleitorais e Sistema partidário no Brasil. 1999. 149 f. Tese (Doutorado em Ciência Política)-Instituto Universitário de Pesquisa do Rio de Janeiro, Rio de Janeiro, 1999.

SOARES, G. D. Alianças e coligações eleitorais: notas para uma teoria. Revista Brasileira de Estudos Políticos, n. 17, p. 95-124, 1964.

SOARES, G. D. A Democracia interrompida. Rio de Janeiro: FGV Editora, 2001.

Recebido: 03 nov., 2014 Aceito: 02 jun., 2015 
Anexo A. Sucesso Eleitoral dos partidos ${ }^{26}$.

Tabela A1. Sucesso eleitoral dos partidos. Eleições 1996 a 2012 . Municípios abaixo de 200 mil eleitores.

\begin{tabular}{|c|c|c|c|c|c|c|c|c|c|c|}
\hline \multirow{2}{*}{ Partidos } & \multicolumn{2}{|c|}{1996} & \multicolumn{2}{|c|}{2000} & \multicolumn{2}{|c|}{2004} & \multicolumn{2}{|c|}{2008} & \multicolumn{2}{|c|}{2012} \\
\hline & $\mathbf{N}$ & $\%$ & $\mathbf{N}$ & $\%$ & $\mathbf{N}$ & $\%$ & $\mathbf{N}$ & $\%$ & $\mathbf{N}$ & $\%$ \\
\hline PMDB & 13 & $16,0 \%$ & 12 & $14,6 \%$ & 38 & $46,3 \%$ & 32 & $39,5 \%$ & 22 & $26,8 \%$ \\
\hline PDT & 7 & $8,6 \%$ & 31 & $37,8 \%$ & 3 & $3,7 \%$ & 3 & $3,7 \%$ & 2 & $2,4 \%$ \\
\hline PSDB & 24 & $29,6 \%$ & 9 & $11,0 \%$ & 3 & $3,7 \%$ & 7 & $8,6 \%$ & 2 & $2,4 \%$ \\
\hline PT & 2 & $2,5 \%$ & 1 & $1,2 \%$ & 7 & $8,5 \%$ & 7 & $8,6 \%$ & 10 & $12,2 \%$ \\
\hline DEM / PFL & 10 & $12,3 \%$ & 4 & $4,9 \%$ & 5 & $6,1 \%$ & 5 & $6,2 \%$ & 2 & $2,4 \%$ \\
\hline Maiores $(n=5)$ & 56 & $69,1 \%$ & 57 & $69,5 \%$ & 56 & $68,3 \%$ & 54 & $66,7 \%$ & 38 & $46,3 \%$ \\
\hline $\begin{array}{c}\text { Maiores s/ } \\
\text { PartGov }(n=4)\end{array}$ & 32 & $39,5 \%$ & 26 & $31,7 \%$ & 18 & $22,0 \%$ & 22 & $27,2 \%$ & 16 & $19,5 \%$ \\
\hline PartGov & 24 & $29,6 \%$ & 31 & $37,8 \%$ & 38 & $46,3 \%$ & 32 & $39,5 \%$ & 22 & $26,8 \%$ \\
\hline $\mathrm{PP} / \mathrm{PPB}$ & 9 & $11,1 \%$ & 9 & $11,0 \%$ & 9 & $11,0 \%$ & 14 & $17,3 \%$ & 8 & $9,8 \%$ \\
\hline PSB & 4 & $4,9 \%$ & 7 & $8,5 \%$ & 1 & $1,2 \%$ & 3 & $3,7 \%$ & 6 & $7,3 \%$ \\
\hline $\begin{array}{l}\text { PR / PL / } \\
\text { PRONA }\end{array}$ & 4 & $4,9 \%$ & 1 & $1,2 \%$ & 3 & $3,7 \%$ & 2 & $2,5 \%$ & 5 & $6,1 \%$ \\
\hline PSC & 1 & $1,2 \%$ & - & $0,0 \%$ & 5 & $6,1 \%$ & 4 & $4,9 \%$ & 7 & $8,5 \%$ \\
\hline PV & 1 & $1,2 \%$ & 4 & $4,9 \%$ & 4 & $4,9 \%$ & - & $0,0 \%$ & 1 & $1,2 \%$ \\
\hline PTB & 2 & $2,5 \%$ & 2 & $2,4 \%$ & 2 & $2,4 \%$ & 1 & $1,2 \%$ & 1 & $1,2 \%$ \\
\hline PSD & 2 & $2,5 \%$ & 1 & $1,2 \%$ & - & $0,0 \%$ & - & $0,0 \%$ & 6 & $7,3 \%$ \\
\hline PRB & - & $0,0 \%$ & - & $0,0 \%$ & - & $0,0 \%$ & 2 & $2,5 \%$ & 4 & $4,9 \%$ \\
\hline PMN & - & $0,0 \%$ & 1 & $1,2 \%$ & 1 & $1,2 \%$ & - & $0,0 \%$ & 2 & $2,4 \%$ \\
\hline PC do B & - & $0,0 \%$ & - & $0,0 \%$ & - & $0,0 \%$ & - & $0,0 \%$ & 2 & $2,4 \%$ \\
\hline PPS & - & $0,0 \%$ & - & $0,0 \%$ & 1 & $1,2 \%$ & - & $0,0 \%$ & - & $0,0 \%$ \\
\hline PTC & - & $0,0 \%$ & - & $0,0 \%$ & - & $0,0 \%$ & 1 & $1,2 \%$ & - & $0,0 \%$ \\
\hline PST & 1 & $1,2 \%$ & - & $0,0 \%$ & - & $0,0 \%$ & - & $0,0 \%$ & - & $0,0 \%$ \\
\hline PSDC & - & $0,0 \%$ & - & $0,0 \%$ & - & $0,0 \%$ & - & $0,0 \%$ & 1 & $1,2 \%$ \\
\hline PSOL & - & $0,0 \%$ & - & $0,0 \%$ & - & $0,0 \%$ & - & $0,0 \%$ & 1 & $1,2 \%$ \\
\hline PRP & 1 & $1,2 \%$ & - & $0,0 \%$ & - & $0,0 \%$ & - & $0,0 \%$ & - & $0,0 \%$ \\
\hline Outros $(n=16)$ & 25 & $30,9 \%$ & 25 & $30,5 \%$ & 26 & $31,7 \%$ & 27 & $33,3 \%$ & 44 & $53,7 \%$ \\
\hline Total & 81 & $100,0 \%$ & 82 & $100,0 \%$ & 82 & $100,0 \%$ & 81 & $100,0 \%$ & 82 & $100,0 \%$ \\
\hline
\end{tabular}

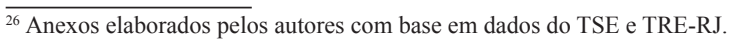


Tabela A2. Sucesso eleitoral dos partidos. Eleições 1996 a 2012. Municípios acima de 200 mil eleitores.

\begin{tabular}{|c|c|c|c|c|c|c|c|c|c|c|}
\hline \multirow{2}{*}{ Partidos } & \multicolumn{2}{|c|}{1996} & \multicolumn{2}{|c|}{2000} & \multicolumn{2}{|c|}{2004} & \multicolumn{2}{|c|}{2008} & \multicolumn{2}{|c|}{2012} \\
\hline & $\mathbf{N}$ & $\%$ & $\mathbf{N}$ & $\%$ & $\mathbf{N}$ & $\%$ & $\mathbf{N}$ & $\%$ & $\mathbf{N}$ & $\%$ \\
\hline PMDB & - & $0 \%$ & 2 & $20 \%$ & 3 & $30 \%$ & 3 & $30 \%$ & 3 & $30 \%$ \\
\hline PDT & 3 & $30 \%$ & 3 & $30 \%$ & 1 & $10 \%$ & 2 & $20 \%$ & 1 & $10 \%$ \\
\hline PSDB & 3 & $30 \%$ & 2 & $20 \%$ & - & $0 \%$ & 1 & $10 \%$ & - & $0 \%$ \\
\hline PT & - & $0 \%$ & - & $0 \%$ & 2 & $20 \%$ & 3 & $30 \%$ & 1 & $10 \%$ \\
\hline DEM / PFL & 2 & $20 \%$ & - & $0 \%$ & 2 & $20 \%$ & - & $0 \%$ & - & $0 \%$ \\
\hline Maiores $(n=5)$ & 8 & $80 \%$ & 7 & $70 \%$ & 8 & $80 \%$ & 9 & $90 \%$ & 5 & $50 \%$ \\
\hline $\begin{array}{c}\text { Maiores s/ } \\
\text { PartGov }(n=4)\end{array}$ & 5 & $50 \%$ & 4 & $40 \%$ & 5 & $50 \%$ & 6 & $60 \%$ & 2 & $20 \%$ \\
\hline PartGov & 3 & $30 \%$ & 3 & $30 \%$ & 3 & $30 \%$ & 3 & $30 \%$ & 3 & $30 \%$ \\
\hline $\mathrm{PP} / \mathrm{PPB}$ & 1 & $10 \%$ & - & $0 \%$ & - & $0 \%$ & - & $0 \%$ & - & $0 \%$ \\
\hline PSB & 1 & $10 \%$ & 1 & $10 \%$ & 1 & $10 \%$ & - & $0 \%$ & 2 & $20 \%$ \\
\hline PR / PL / PRONA & - & $0 \%$ & - & $0 \%$ & - & $0 \%$ & 1 & $10 \%$ & 2 & $20 \%$ \\
\hline PV & - & $0 \%$ & - & $0 \%$ & 1 & $10 \%$ & - & $0 \%$ & - & $0 \%$ \\
\hline РTB & - & $0 \%$ & 1 & $10 \%$ & - & $0 \%$ & - & $0 \%$ & - & $0 \%$ \\
\hline PC do B & - & $0 \%$ & - & $0 \%$ & - & $0 \%$ & - & $0 \%$ & 1 & $10 \%$ \\
\hline PPS & - & $0 \%$ & 1 & $10 \%$ & - & $0 \%$ & - & $0 \%$ & - & $0 \%$ \\
\hline Outros $(n=7)$ & 2 & $20 \%$ & 3 & $30 \%$ & 2 & $20 \%$ & 1 & $10 \%$ & 5 & $50 \%$ \\
\hline Total & 10 & $100 \%$ & 10 & $100 \%$ & 10 & $100 \%$ & 10 & $100 \%$ & 10 & $100 \%$ \\
\hline
\end{tabular}

\section{Notas de pesquisa sobre os Gráficos A1 a A5.}

Este gráfico é uma reprodução de Kendall e Lazarsfeld (1950) utilizado por Emerson Cervi (2013) no qual são descritos as regiões de interações do Teste Q-Y. A Região A indicaria que as associações estariam muito próximas de zero, não havendo relação entre $\mathrm{X}$ e Y e nem o controle T. A Região B indica que a associação entre $\mathrm{X}$ e $\mathrm{Y}$ é significativa, porém o teste $\mathrm{T}$ é próximo de zero, indicando que o controle é que explicaria $\mathrm{Y}$ e não a variável X. A Região C mostra que a relação X e Y não depende do controle $T$, sendo este não significativo. A Região D mostra um valor maior de T do que a relação X e Y, ou seja, haveria um forte efeito da terceira variável. E, por último, a Região $\mathrm{E}$ indicar que tanto as relações $\mathrm{X}$ e $\mathrm{Y}$ são fortes, quanto o controle $\mathrm{T}$, havendo uma oscilação entre poder ou não explicar a relação (CERVI, 2013).

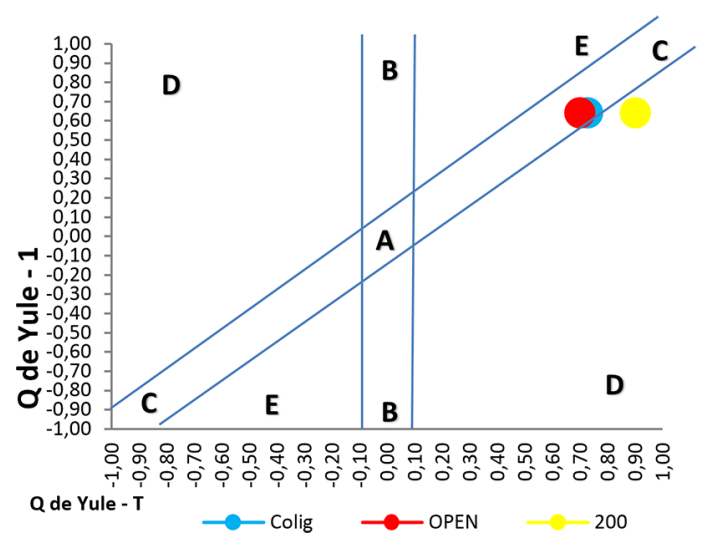

Gráfico A1. Gráfico do Testes de Associação Q-Y com uma terceira variável (GOV × Eleitos). 


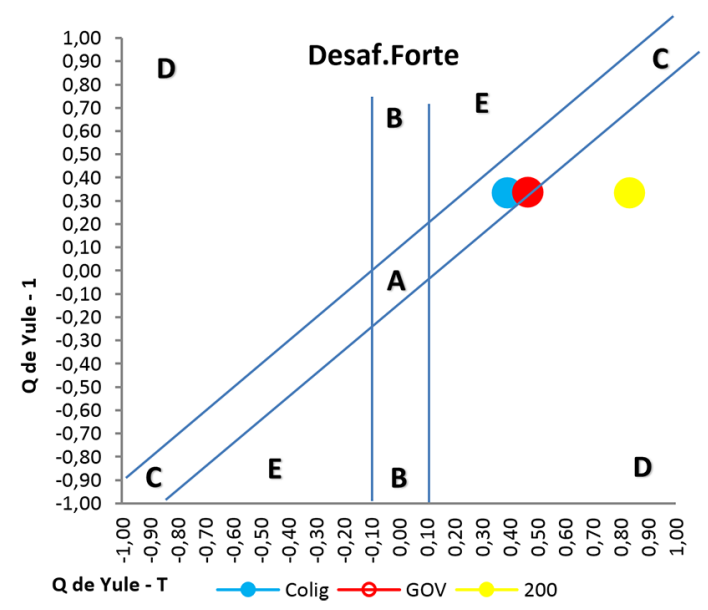

Gráfico A2. Gráfico do Testes de Associação Q-Y com uma terceira variável (Desaf. Forte $\times$ Eleitos).

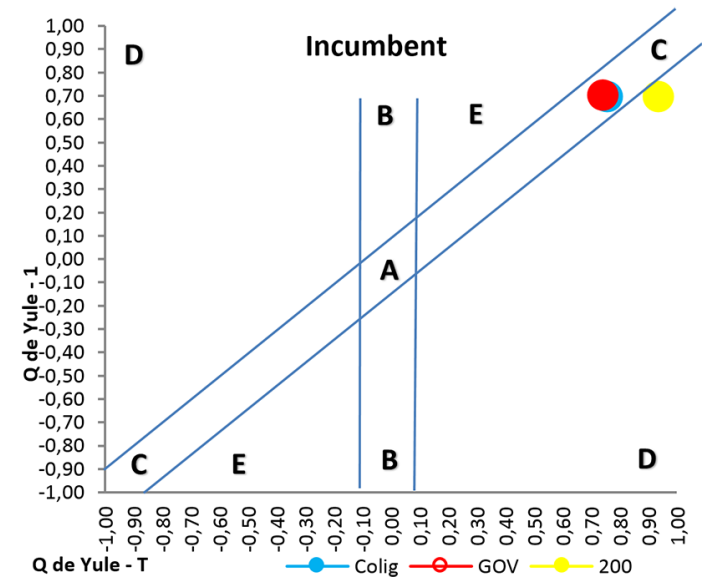

Gráfico A3. Gráfico do Testes de Associação Q-Y com uma terceira variável (Incumbent $\times$ Eleitos).

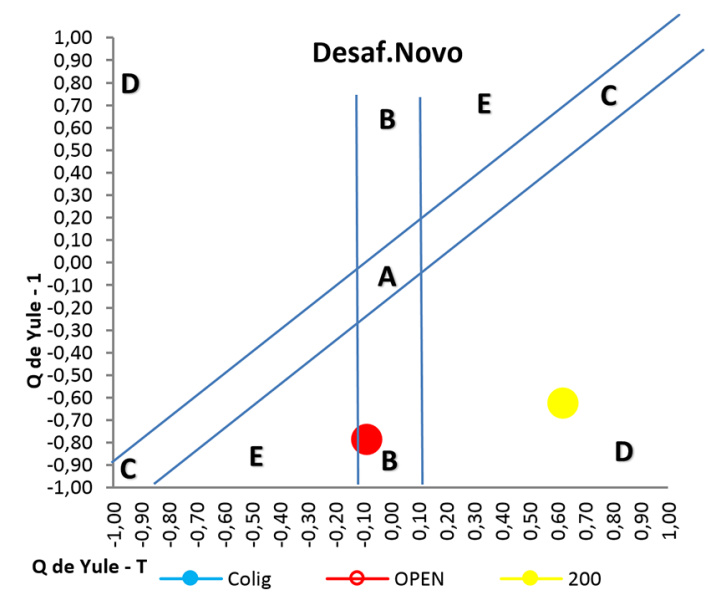

Gráfico A4. Gráfico do Testes de Associação Q-Y com uma terceira variável (Desaf. Novo $\times$ Eleitos). 


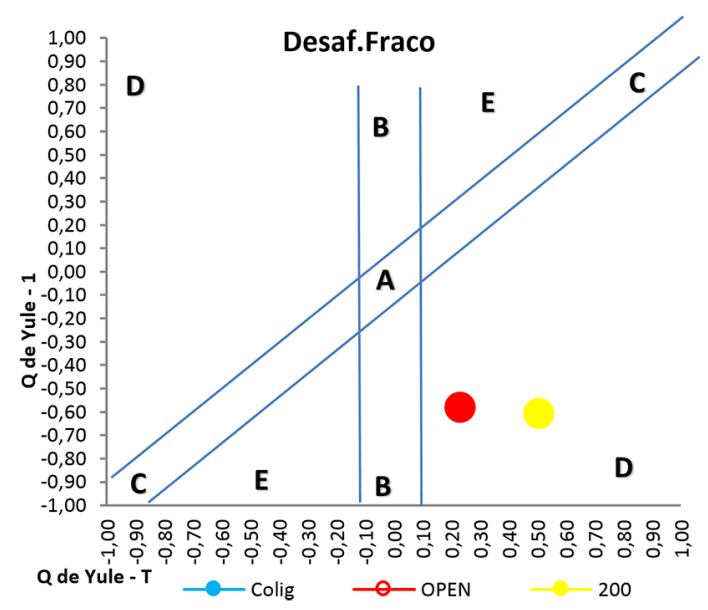

Gráfico A5. Gráfico do Testes de Associação Q-Y com uma terceira variável (Desaf. Fraco $\times$ Eleitos). 